\title{
Performance and nitrogen use efficiency in mid-lactation dairy cows fed timothy cut in the afternoon or morning
}

\author{
A. F. Brito, ${ }^{\star}$ G. F. Tremblay,† A. Bertrand,† Y. Castonguay,† G. Bélanger, $\uparrow$ R. Michaud,† C. Lafrenière,† \\ R. Martineau, $\S$ and R. Berthiaume\# ${ }^{1}$ \\ *Department of Biological Sciences, University of New Hampshire, Durham 03824 \\ †Soils and Crops Research and Development Centre, Agriculture and Agri-Food Canada, Québec City, QC, Canada G1V 2J3 \\ fUniversité du Québec en Abitibi-Témiscamingue, Rouyn-Noranda, QC, Canada J9X 5E4 \\ §Dairy and Swine Research and Development Centre, Agriculture and Agri-Food Canada, Sherbrooke, QC, Canada J1M $1 Z 3$ \\ \#Valacta, Dairy Production Centre of Expertise Québec-Atlantic, Sainte-Anne-de-Bellevue, QC, Canada H9X 3R4
}

\begin{abstract}
Shifting cutting from morning to afternoon has been shown to increase the concentration of nonstructural carbohydrates in forages. We hypothesized that, compared with a total mixed ration containing timothy baleage and silage cut in the morning (a.m.-cut TIM), a total mixed ration containing timothy baleage and silage cut in the afternoon (p.m.-cut TIM) would improve animal performance and $\mathrm{N}$ use efficiency in mid-lactation Holstein cows due to enhanced supply of ruminal fermentable energy. The objective of this study was to compare the effects of p.m.- versus a.m.-cut TIM on milk yield, concentrations and yields of milk components, ruminal metabolism, and plasma concentrations of AA in mid-lactation Holstein cows. Ten (6 ruminally cannulated) primiparous cows averaging $139 \pm 13 \mathrm{~d}$ in milk and $550 \pm 56 \mathrm{~kg}$ of body weight, and 6 (2 ruminally cannulated) multiparous cows averaging $128 \pm 11$ $\mathrm{d}$ in milk and $632 \pm 57 \mathrm{~kg}$ of body weight at the beginning of the experiment, were used in a crossover design. Each period lasted $21 \mathrm{~d}$ with $14 \mathrm{~d}$ for diet adaptation and $7 \mathrm{~d}$ for data and sample collection. The concentration of nonstructural carbohydrates (water-soluble carbohydrates plus starch) was numerically greater in the p.m.- versus the a.m.-cut TIM and averaged 13.2 $\pm 1.06 \%$ and $12.2 \pm 1.13 \%$, respectively. Treatment $\times$ parity effects were observed for milk urea $\mathrm{N}$, feed efficiency, and milk $\mathrm{N}$ efficiency, whereas parity effects were observed for nutrient intake, milk yield, and plasma concentration of several essential and nonessential AA. Intakes of dry matter (19.3 versus $18.6 \mathrm{~kg} / \mathrm{d})$ and nonstructural carbohydrates (2.56 versus $2.31 \mathrm{~kg} / \mathrm{d}$ ), and yields of $4 \%$ fat-corrected milk (23.1 versus $22.2 \mathrm{~kg} / \mathrm{d}$ ), energy-corrected milk ( 25.0 versus $24.1 \mathrm{~kg} / \mathrm{d}$ ), milk fat (0.91 versus $0.88 \mathrm{~kg} / \mathrm{d}$ ), and milk protein ( 0.77 versus
\end{abstract}

Received November 4, 2015.

Accepted March 1, 2016.

${ }^{1}$ Corresponding author: rberthiaume@valacta.com
$0.73 \mathrm{~kg} / \mathrm{d}$ ) were all greatest with feeding p.m.-cut TIM. Milk yield (23.5 versus $22.7 \mathrm{~kg} / \mathrm{d}$ ) tended to increase in cows fed p.m.-cut TIM. The ruminal fermentation profiles and plasma concentrations of AA were mostly unaffected by treatments. However, ruminal valerate (1.01 versus $1.17 \mathrm{~mol} / 100 \mathrm{~mol})$ and plasma Gly (172 versus $188 \mu M$ ) were lowest with feeding p.m.-cut TIM. Overall, feeding mid-lactation dairy cows a total mixed ration that consisted of p.m.-cut timothy baleage and silage significantly increased dry matter intake and yields of milk, milk fat, and milk protein.

Key words: dairy cow, milk yield, nonstructural carbohydrates, timothy

\section{INTRODUCTION}

In general, forage sources are rich in RDP but poor in NSC [defined herein as water-soluble carbohydrates (WSC) or total ethanol soluble carbohydrates (TESC) plus starch], leading to unbalanced supplies of $\mathrm{NH}_{3}-\mathrm{N}$ and fermentable energy in the rumen. Plant $\mathrm{C}$ fixation occurs at a greater rate than $\mathrm{C}$ exportation during daylight, resulting in accumulation of NSC in tissues of grasses and legumes as the day progresses (Bowden et al., 1968; Lechtenberg et al., 1971; Gordon, 1996; Morin et al., 2011). Delaying cutting from early morning to late afternoon has been shown to increase the concentrations of NSC in legumes such as alfalfa (Medicago sativa L.; Brito et al., 2008) and red clover (Trifolium pratense L.) (Pelletier et al., 2010; Antaya et al., 2015). Shifting cutting from morning to afternoon has also been shown to increase the concentrations of NSC in several grass species including orchardgrass (Dactylis glomerata L.) (Burner and Belesky, 2004), gamagrass [Tripsacum dactyloides L.] and switchgrass (Panicum virgatum L.) (Huntington and Burns, 2007), and tall fescue [Schedonorus phoenix (Scop.) Holub], reed canarygrass (Phalaris arundinacea L.), smooth bromegrass (Bromus inermis Leyss), meadow bromegrass (Bromus biebersteinii Roemer \& J.A. Schultes), 
and Kentucky bluegrass (Poa pratensis L.; Pelletier et al., 2010). Collectively, these data confirm that most forage species are likely to have a greater NSC concentration when cut in the afternoon than in the morning.

Timothy (Phleum pratense L.) is one of the most important cool-season grasses grown in cold regions of North America, Scandinavia, Russia, and Japan (Berg et al., 1996). Our group was the first to demonstrate that daytime cutting management affects the concentration of NSC in timothy (Bertrand et al., 2008; Pelletier et al., 2009, 2010; Morin et al., 2012). Specifically, Bertrand et al. (2008) showed that the concentration of NSC was $29 \%$ greater in timothy herbage harvested in the afternoon than in the morning, which was primarily driven by a proportional increase in sucrose concentration (+46\%). Similarly, Pelletier et al. (2009) showed that timothy cut in the afternoon had greater concentrations of NSC $(+53 \%)$, WSC $(+60 \%)$, and sucrose $(+87 \%)$ compared with timothy cut in the morning. More recently, Pelletier et al. (2010) demonstrated that among 8 forage species, timothy ranked third behind red clover and tall fescue in the concentration of NSC (mean $=8.42 \%)$ across cutting times and growth periods. To the best of our knowledge, we are not aware of any study to date in which lactating dairy cows were fed TMR consisted of p.m.- versus a.m.-cut timothy baleage or silage.

We hypothesized that, compared with a TMR containing timothy baleage and silage cut in the morning (a.m.-cut TIM), a TMR containing timothy baleage and silage cut in the afternoon (p.m.-cut TIM) would improve performance and $\mathrm{N}$ use efficiency in mid-lactation Holstein cows due to enhanced ruminal supply of readily fermentable energy. The objective of this study was to compare the effects of p.m.- versus a.m.-cut TIM on milk yield, concentrations and yields of milk components, ruminal metabolism, and plasma concentrations of AA in mid-lactation Holstein cows.

\section{MATERIALS AND METHODS}

Care and handling of the animals used in the current experiment were conducted as outlined in the guidelines of the Canadian Council on Animal Care (1993). This study was approved by the Institutional Animal Care Committee of the Dairy and Swine Research and Development Centre (Sherbrooke, QC, Canada).

\section{Timothy Cut and Harvest}

The timothy (cultivar 'Champ') herbage harvested as baleage and used in the current study was grown in an 8-ha field (95\% timothy and 5\% red clover) located at the Agriculture and Agri-Food Canada Normandin
Research Farm in Normandin $\left(48^{\circ} 51^{\prime} \mathrm{N}, 72^{\circ} 32^{\prime} \mathrm{W}\right.$; QC, Canada). The summer regrowth (i.e., second cut) of half of the field was cut on August 26, 2008, in the afternoon (1800 to 2030 h; p.m.-cut timothy baleage), whereas the second half of the field was cut on August 27, 2008, in the morning (0600 to $0830 \mathrm{~h}$; a.m.-cut timothy baleage). Timothy was cut at the heading stage of development (stages 58 to 60; Simon and Park, 1983) yielding approximately $2 \mathrm{t}$ of $\mathrm{DM} /$ ha. Forage was cut using a conventional mower conditioner, tedded, and field-wilted to about $60 \% \mathrm{DM}$, which was attained at approximately $1200 \mathrm{~h}$ on August 28, 2008. Between 1230 and $1330 \mathrm{~h}$ in the afternoon of August 28, 2008, p.m.- and then a.m.-cut timothy were harvested as baleage using a large rectangular baler (New Idea model 7333, Agco Corporation, Duluth, GA) and wrapped with stretch plastic using a bale wrapper (Équipement Anderson model 680-S, Chesterville, QC, Canada). Minimum and maximum air temperatures were, respectively, 11.4 and $21.3^{\circ} \mathrm{C}$ on August $26,5.8$ and $24.1^{\circ} \mathrm{C}$ on August 27, and 8.5 and $25.9^{\circ} \mathrm{C}$ on August 28, 2008. The global radiation observed the day before cutting (i.e., August 25,2008 ) averaged $20.6 \mathrm{MJ} / \mathrm{m}^{2}$ compared with a clear sky maximum value of $26.5 \mathrm{MJ} / \mathrm{m}^{2}$ potentially expected at this location. A total of 84 bales ( 42 p.m.cut and 42 a.m.-cut) were made and later transported to the Dairy and Swine Research and Development Centre of Agriculture and Agri-Food Canada located in Sherbrooke $\left(45^{\circ} 24^{\prime} \mathrm{N}, 71^{\circ} 54^{\prime} \mathrm{W}\right.$; QC, Canada) for the animal study. The time elapsed between timothy baling and feeding to the cows (d 1 of the study) was approximately $150 \mathrm{~d}$.

The timothy (cultivar 'Champ') silage used in the current study was grown in 2 pure stand fields (total of 16 ha) located at the Dairy and Swine Research and Development Centre Farm (Sherbrooke, QC, Canada). The spring growth (i.e., first cut) of half of the field was cut on June 12, 2008, in the afternoon (1800 to 2030 h; p.m.-cut timothy silage), whereas the second half of the field was cut on June 13, 2008 in the morning (0600 to 0830 h; a.m.-cut timothy silage). Timothy was cut and harvested as silage at the heading stage of development, yielding approximately $3 \mathrm{t}$ of $\mathrm{DM} /$ ha. Forage was cut using 2 mower conditioners (model 4032 WA; Kverneland Group, Drummondville, QC, Canada) and field-wilted to about 30\% DM, which was attained at approximately $1500 \mathrm{~h}$ on June 13, 2008. Between 1500 and 2000 h of June 13, 2008, p.m.- and then a.m.-cut timothy were harvested as silage using a forage harvester (model 900, New Holland Agriculture, Turin, Italy) and stored in 2 silo plastic bags using a $9^{\prime}$ model silo bagger (Kelly Ryan, Blair, NE). Minimum and maximum air temperatures were, respectively, 8.9 and $19.8^{\circ} \mathrm{C}$ on June 12 , and 6.0 and $25.8^{\circ} \mathrm{C}$ on June 
13, 2008. The global radiation observed the day before cutting (i.e., June 11, 2008) averaged $31.6 \mathrm{MJ} / \mathrm{m}^{2} \mathrm{com}$ pared with a clear sky maximum value of $34.3 \mathrm{MJ} / \mathrm{m}^{2}$ potentially expected at this location. The time elapsed between timothy ensiling and feeding to the cows (d 1 of the study) was approximately $225 \mathrm{~d}$.

\section{Animals, Experimental Design, and Diets}

Ten (6 ruminally cannulated) primiparous Holstein cows averaging (mean \pm SD) $139 \pm 13$ DIM, $550 \pm$ $56 \mathrm{~kg}$ of BW, and $26.9 \pm 3.64 \mathrm{~kg}$ of milk yield and 6 (2 ruminally cannulated) multiparous Holstein cows averaging $128 \pm 11 \mathrm{DIM}, 632 \pm 57 \mathrm{~kg}$ of $\mathrm{BW}$, and $34 \pm$ $3.6 \mathrm{~kg}$ of milk yield at the beginning of the experiment were blocked by DIM, milk yield, and parity. Within each block, cows were randomly assigned to 2 treatments (p.m.- or a.m.-cut TIM) in a crossover design. The 2-stage rumen cannulation technique as described by Martineau et al. (2015) was used to perform the surgeries. Each period lasted $21 \mathrm{~d}$ (total of $42 \mathrm{~d}$ ) and consisted of $14 \mathrm{~d}$ for diet adaptation and $7 \mathrm{~d}$ for data and sample collection. A TMR (DM basis) containing $34.2 \%$ of a soybean meal/cracked corn-based concentrate mix plus (1) $46.5 \%$ p.m.-cut timothy baleage and $19.3 \%$ p.m.-cut timothy silage (p.m.-cut TIM diet) or (2) $46.5 \%$ a.m.-cut timothy baleage and $19.3 \%$ a.m.cut timothy silage (a.m.-cut TIM diet) was offered ad libitum to the cows once daily at approximately $0900 \mathrm{~h}$. Orts were collected daily at $0800 \mathrm{~h}$, and the amount of TMR offered to the cows was adjusted daily to yield refusals equal to approximately 5 to $10 \%$ of intake. Cows were housed in a tie stall barn and had free access to water throughout the experiment.

The following ingredients were used in the concentrate (\% of DM): cracked corn $(46 \%)$, soybean meal $(47 \%)$, and a mineral plus vitamin premix $(7 \%)$. The mineral plus vitamin premix contained (as fed): magnesium oxide $(37.5 \mathrm{~g} / \mathrm{kg})$, vitamin E/Se supplement $(87.5$ $\mathrm{g} / \mathrm{kg})$, sodium bicarbonate $(219 \mathrm{~g} / \mathrm{kg})$, limestone $(219$ $\mathrm{g} / \mathrm{kg})$, sodium chloride $(31.2 \mathrm{~g} / \mathrm{kg})$, and a micromineral/vitamin supplement $(406 \mathrm{~g} / \mathrm{kg})$. The mineral plus vitamin premix provided (per kilogram of premix DM): $153 \mathrm{~g}$ of $\mathrm{Ca}, 21.2 \mathrm{~g}$ of P, $47.1 \mathrm{~g}$ of $\mathrm{Mg}, 208 \mathrm{~g}$ of Na, 145 $\mathrm{g}$ of $\mathrm{Cl}, 1,227 \mathrm{mg}$ of Fe, 2,306 $\mathrm{mg}$ of $\mathrm{Zn}, 1,540 \mathrm{mg}$ of $\mathrm{Mn}, 461 \mathrm{mg}$ of $\mathrm{Cu}, 46.1 \mathrm{mg}$ of I, $16.9 \mathrm{mg}$ of Co, 12.7 $\mathrm{mg}$ of Se, $0.8 \mathrm{~g}$ of K, $1.3 \mathrm{~g}$ of S, 207,360 IU of vitamin A, 45,280 IU of vitamin D, and 1,063 IU of vitamin E.

\section{Bales Ranking and Feed Sampling and Analyses}

Three to 4 cores were made in each bale $(\mathrm{n}=84)$ using an electric drill fitted with a metal core sampler approximately $82 \mathrm{~d}$ before the beginning of the experi- ment with cores composited to yield individual 200-g sample sizes. Samples were then lyophilized, ground to pass through a 1-mm screen (Wiley mill, Arthur H. Thomas, Philadelphia, PA), and individually analyzed for sucrose, glucose, fructose, and starch as described in detail later. Water-soluble carbohydrates were calculated by combining sucrose, glucose, and fructose, whereas NSC was obtained by adding WSC plus starch. To rank and pair bales, the NSC (WSC plus starch) concentrations of all 84 bales were calculated as described above. Second, bales were ranked from the greatest to the smallest NSC concentration. Third, the p.m.-cut bale with the greatest NSC concentration was paired with the a.m.-cut bale with the greatest NSC concentration with this pairing procedure repeated to create 42 pairs that were randomly assigned to each of the 42 experimental days. This ranking and pairing procedure was developed to maintain consistent differences in NSC concentrations between the p.m.- and a.m.-cut baleages throughout the duration of the experiment as previously reported (Brito et al., 2008, 2014).

Baleage, silage, and concentrate samples were collected daily during the sampling periods (i.e., d 15 to 21), lyophilized, ground (1-mm screen; Wiley mill), and pooled by mixing equal amounts of dried samples from individual sources. Samples of TMR were collected daily during the sampling periods, lyophilized, and ground (1-mm screen; Wiley mill). Pooled samples of forages and concentrates, and individual samples of TMR were analyzed for sucrose, fructose, glucose, high-degree of polymerization (HDP) fructans, and starch. Extraction and determination of WSC fractions were done according to Bertrand et al. (2007). Briefly, WSC were extracted from dried samples with a methanol:chloroform:water solution $(12: 5: 3, \mathrm{vol} / \mathrm{vol} / \mathrm{vol})$ and analyzed by a HPLC system controlled by a Waters Millennium ${ }^{32}$ software (Waters, Milford, MA) and equipped with a model 515 pump, a model $717^{\text {plus }}$ autosampler, and a model 2410 refractive index detector. Sucrose, fructose, and glucose were separated on a Waters Sugar-Pak column (Waters) and detected on a refractive index detector. Peak identity and quantity were determined by comparison with standards. The nonsoluble residues left after the methanol:chloroform:water extraction were washed twice with methanol and used for starch quantification as a glucose equivalent with the $p$-hydroxybenzoic acid hydrazide method of Blakeney and Mutton (1980) after gelatinization at $100^{\circ} \mathrm{C}$ and digestion for $90 \mathrm{~min}$ with amyloglucosidase (Sigma A7255, Sigma Chemical Co., St. Louis, MO). Fructans from dried samples were extracted in water. High degree of polymerization fructans were separated on a Shodex KS-804 column preceded by a Shodex KS-G precolumn (Shodex, Tokyo, Japan) eluted isocratically at $50^{\circ} \mathrm{C}$ with deionized water at a 
flow rate of $1.0 \mathrm{~mL} / \mathrm{min}$, and analyzed on a Waters 2410 refractive index detector. The degree of polymerization of HDP fructans was estimated by reference to a standard curve established with 7 polymaltotriose pullulan standards (Shodex Standard P-82) ranging from $0.58 \times 10^{4}$ to $85.3 \times 10^{4}$ of molecular weight. Fructan concentrations were determined by reference to a fructose standard curve. Fructans in timothy are highly polymerized (Suzuki, 1993), and based on our previous work, no low degree of polymerization fructans were detected in timothy samples harvested at heading and anthesis stages of development (Pelletier et al., 2009). Therefore, only HDP fructans were analyzed in the current study.

Differential solubilities of baleage, silage, concentrate, and TMR carbohydrates in 80:20 (vol/vol) ethanol:water were used to partition the neutral detergent soluble carbohydrates into organic acids, and mono- and oligosaccharides, which are soluble from starch, and neutral detergent soluble fiber, which is insoluble in aqueous ethanol (Hall et al., 1999; Hall, 2000). Mono- and oligosaccharides were measured colorimetrically in the ethanol:water extract using the phenol-sulfuric acid method of Dubois et al. (1956) with a sucrose standard, whereas starch was analyzed enzymatically on the ethanol:water insoluble residue following the method of Holm et al. (1986) as modified by Hall (2000). Glucose hydrolyzed from starch was measured using glucose oxidase-peroxidase reagent (Karkalas, 1985).

Baleage, silage, concentrate, and TMR samples were also analyzed for analytical DM (method 930.15; AOAC International, 2006) and ash with a thermogravimetric analyzer (model TGA-601, Leco Corporation, St. Joseph, MI); total N, NDIN, and ADIN using micro-Kjeldahl analysis (Kjeltec 2400 instrument, Foss Analytical, Hillerød, Denmark; method 976.06; AOAC International, 2006); NDF and ADF with the Ankom ${ }^{200}$ fiber analyzer (Ankom Technology, Fairport, NY) using heat-stable $\alpha$-amylase and sodium sulfite (Van Soest et al., 1991); and crude fat with a Soxtec system HT6 apparatus (Tecator, Fisher Scientific, Montreal, Canada). Concentrations of AA in feeds and TMR samples were determined by the isotope dilution method of Calder et al. (1999) after a 24-h acid hydrolysis with $6 \mathrm{~N}$ $\mathrm{HCl}$-phenol at $110^{\circ} \mathrm{C}$ (AOAC International, 2000) as described by Borucki Castro et al. (2007). A second acid hydrolysis using performic acid oxidation was performed for the analysis of Met (method 994.12; AOAC International, 2000). A mixture of labeled AA $\left({ }^{13} \mathrm{C}\right.$ and ${ }^{15} \mathrm{~N}$ AA isotope standards, $\mathrm{CDN}$ isotopes, Pointe-Claire, QC, Canada; Cambridge Isotope Laboratories Inc., Andover, MA) was used as an internal standard. Amino acid enrichment was quantified using a GC-MS (Hewlett-Packard model GC6890-MS5973, Agilent Technologies, Wilmington, DE). Silage extracts were prepared and analyzed as reported by Brito et al. (2014). Orts collected from d 15 to 21 in each period were pooled by cow, stored at $-20^{\circ} \mathrm{C}$, lyophilized, and ground to pass through a $1-\mathrm{mm}$ screen. Samples were then analyzed for analytical DM, ash, total N, NDF, and ADF using the procedures described above. The nutrient compositions of baleages, silages, and concentrate are presented in Table 1, whereas the ingredient and nutrient compositions of the experimental TMR are presented in Table 2. The AA profiles of diets and feeds are presented in Table 3.

\section{Ruminal Sampling and Analyses}

Samples of whole ruminal contents (about $200 \mathrm{~g}$ ) were taken from the ventral sac of 8 ruminally cannulated cows (6 multiparous and 2 primiparous) at 0700, 0800, 1100, 1400, 1700, and $2000 \mathrm{~h}$ on d 15, 1000, 1300, 1600, and $1900 \mathrm{~h}$ on d 16, and 0900, 1200, 1500, and $1800 \mathrm{~h}$ on d 17 of each period. Ruminal digesta samples were strained through 2 layers of cheesecloth with $\mathrm{pH}$ measurements (pH/temp meter 199 model No 3D, Fisher Scientific, Pittsburgh, PA) immediately afterward. Two 10 -mL samples were then preserved by addition of 0.2 $\mathrm{mL}$ of $50 \% \mathrm{H}_{2} \mathrm{SO}_{4}$ and stored at $-20^{\circ} \mathrm{C}$ until analysis. Samples were thawed at room temperature, centrifuged $\left(25,200 \times g, 15 \mathrm{~min}, 4^{\circ} \mathrm{C}\right)$, and supernatants analyzed for $\mathrm{NH}_{3}-\mathrm{N}$ using the indophenol-blue method of Novozamsky et al. (1974) and for VFA with a GLC instrument (Hewlett-Packard 6890N, Hewlett-Packard Inc., Montreal, QC, Canada) equipped with a flameionization detector and a 7683B model autosampler as described by Delbecchi et al. (2001).

\section{Blood Sampling and Analyses}

Approximately $4 \mathrm{~h}$ after feeding on d 18 of each period, coccygeal blood samples were taken and collected into Vacutainer tubes (Becton Dickinson, Franklin Lakes, NJ) from all 16 cows. Vacutainer tubes containing sodium heparin were used for AA and urea-N analyses, whereas tubes without anticoagulant were used for nonesterified fatty acids (NEFA) determination. After sampling, tubes were kept on ice and centrifuged $\left(2,000 \times g, 12 \mathrm{~min}, 4^{\circ} \mathrm{C}\right)$. For analysis of AA, $0.2 \mathrm{~g}$ of an internal standard solution of stable isotope-labeled AA was gravimetrically added to $1.0 \mathrm{~g}$ of plasma before storage at $-80^{\circ} \mathrm{C}$ (Martineau et al., 2007). Plasma concentrations of individual AA were determined by the isotope dilution method using a GC-MS as previously described. The remaining plasma was stored at $-20^{\circ} \mathrm{C}$ for later analysis of plasma urea $\mathrm{N}$ with a Technicon 
Table 1. Nutrient composition (\% DM, unless otherwise noted) of p.m.- and a.m.-cut timothy baleage, p.m.- and a.m.-cut timothy silage, and a corn-soybean meal mix concentrate fed to mid-lactation dairy cows

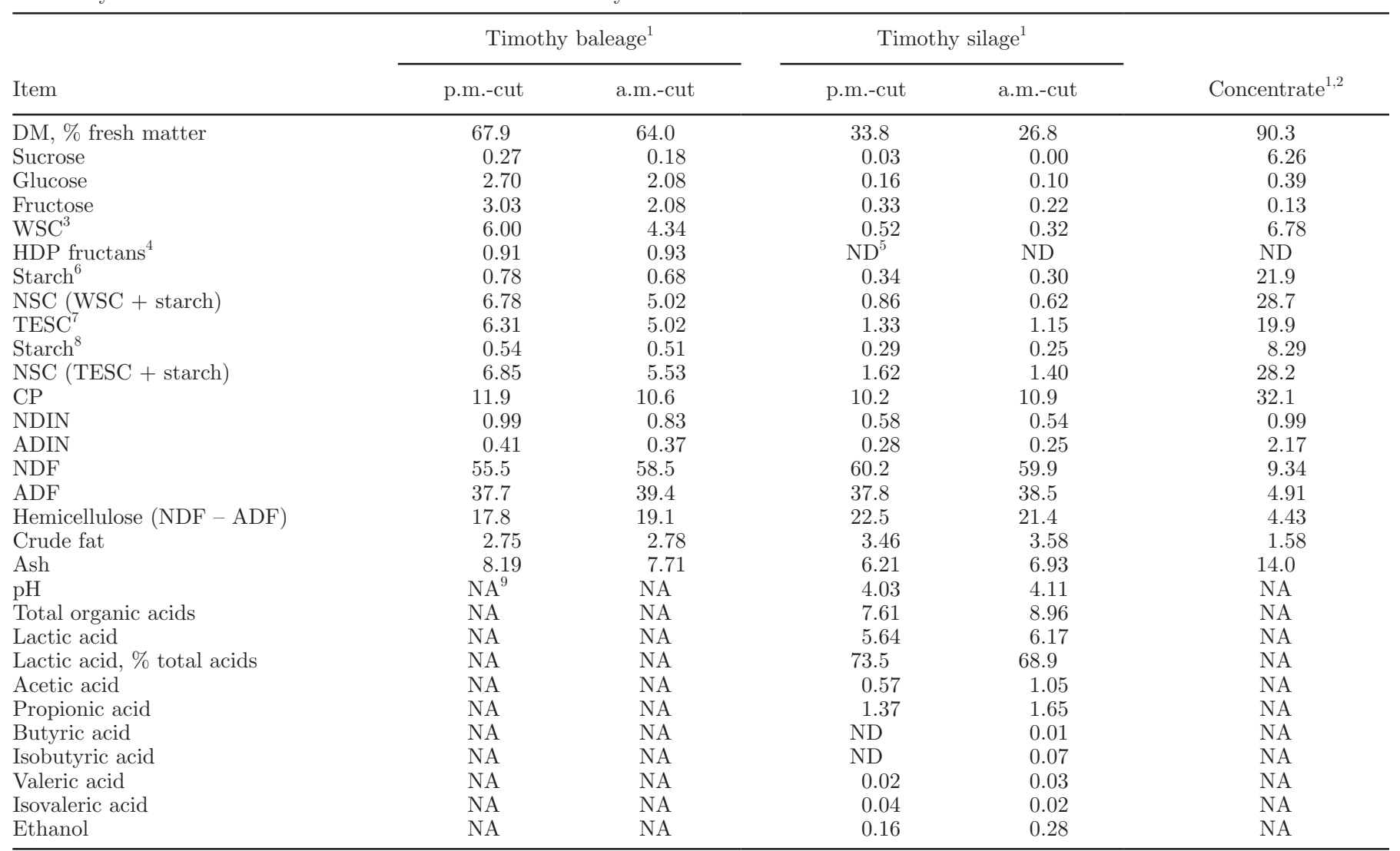

${ }^{1}$ Samples were pooled within each sampling period (d 15 to 21$)$.

${ }^{2}$ The concentrate mix was composed (DM basis) by cracked corn (45.9\%), soybean meal (47.1\%), and a mineral plus vitamin premix $(6.98 \%)$.

${ }^{3} \mathrm{WSC}=$ water-soluble carbohydrates (sucrose + glucose + fructose).

${ }^{4} \mathrm{HDP}$ fructans $=$ high-degree of polymerization fructans.

${ }^{5} \mathrm{ND}=$ not detected.

${ }^{6}$ Analyzed as glucose equivalent using $p$-hydroxybenzoic acid hydrazide after extraction with methanol-chloroform-water (Blakeney and Mutton, 1980).

${ }^{7}$ TESC $=$ total ethanol soluble carbohydrates

${ }^{8}$ Analyzed as glucose equivalent using oxidase-peroxidase after sample extraction with ethanol (Hall, 2000).

${ }^{9} \mathrm{NA}=$ not analyzed.

autoanalyzer (industrial method no. 339-01; Technicon Instruments, Tarrytown, NY) and NEFA with a commercial kit (Wako Pure Chemical Industries Ltd., Osaka, Japan) according to McCutcheon and Bauman (1986).

\section{Animal Performance and Milk Analyses}

Cows were milked twice daily at approximately 0600 and $2000 \mathrm{~h}$, and milk yield was recorded at each milking from all 16 cows. Milk samples from a.m. and p.m. milkings were collected from d 14 (p.m.) to d 21 (a.m.) of each experimental period, preserved in tubes containing 2-bromo-2-nitropropan 1,3 diol, and kept at $4^{\circ} \mathrm{C}$ until being shipped for determination of fat, protein, lactose, and MUN by mid-infrared reflectance spectroscopy (Valacta, Sainte-Anne-de-Bellevue, QC, Canada). Concentrations and yields of milk components and MUN were computed as the weighted means from a.m. and p.m. milk yields on each test day. Feed efficiency was computed by dividing mean milk yield by mean DMI over the last $7 \mathrm{~d}$ of each period. Apparent efficiency of utilization of feed $\mathrm{N}$ was calculated by dividing mean milk $\mathrm{N}$ secretion (milk $\mathrm{N}$ concentration $\times$ milk yield) by mean $\mathrm{N}$ intake over the last $7 \mathrm{~d}$ of each period. Body weights were recorded after the a.m. milking for 3 consecutive days at the beginning of the experiment and at the end of each period to compute ADG. 


\section{Statistical Analyses}

Data were analyzed using the MIXED procedure of SAS (version 9.4, SAS Institute Inc., Cary, NC) according to a crossover design. The following model was fitted for all variables with no repeated measures over time:

$$
\begin{gathered}
Y_{\mathrm{ijk} l}=\mu+\mathrm{S}_{\mathrm{i}}+\mathrm{C}_{\mathrm{j}}(\mathrm{S})_{\mathrm{i}}+\mathrm{T}_{\mathrm{k}}+\mathrm{ST}_{\mathrm{ik}}+\mathrm{PAR}_{\mathrm{l}} \\
+\mathrm{TPAR}_{\mathrm{kl}}+\varepsilon_{\mathrm{ijkl}},
\end{gathered}
$$

Table 2. Ingredient, nutrient composition, and NRC (2001) estimations of TMR that consisted of p.m.-cut timothy baleage and silage (p.m.-cut TIM) or a.m.-cut timothy baleage and silage (a.m.-cut TIM) plus a corn-

\begin{tabular}{|c|c|c|}
\hline \multirow[b]{2}{*}{ Item } & \multicolumn{2}{|c|}{ Treatment $^{1}$} \\
\hline & p.m.-cut TIM & a.m.-cut TIM \\
\hline \multicolumn{3}{|l|}{ Diet ingredient composition } \\
\hline p.m.-cut timothy baleage & 46.5 & - \\
\hline p.m.-cut timothy silage & 19.3 & - \\
\hline a.m.-cut timothy baleage & - & 46.5 \\
\hline a.m.-cut timothy silage & - & 19.3 \\
\hline Concentrate mix $^{2}$ & 34.2 & 34.2 \\
\hline \multicolumn{3}{|l|}{ Diet nutrient composition } \\
\hline DM, \% fresh matter & $55.8 \pm 1.46$ & $51.4 \pm 1.68$ \\
\hline Sucrose & $1.33 \pm 0.23$ & $1.20 \pm 0.13$ \\
\hline Glucose & $1.52 \pm 0.16$ & $1.27 \pm 0.15$ \\
\hline Fructose & $1.65 \pm 0.28$ & $1.23 \pm 0.15$ \\
\hline $\mathrm{WSC}^{3}$ (sucrose + glucose + fructose) & $4.50 \pm 0.40$ & $3.70 \pm 0.26$ \\
\hline HDP fructans ${ }^{4}$ & $1.04 \pm 0.06$ & $1.10 \pm 0.10$ \\
\hline Starch $^{5}$ & $8.66 \pm 1.20$ & $8.47 \pm 1.07$ \\
\hline NSC (WSC + starch) & $13.2 \pm 1.06$ & $12.2 \pm 1.13$ \\
\hline TESC $^{6}$ & $5.65 \pm 0.44$ & $5.03 \pm 0.35$ \\
\hline Starch $^{7}$ & $7.65 \pm 1.15$ & $7.60 \pm 1.03$ \\
\hline NSC (TESC + starch) & $13.3 \pm 1.15$ & $12.6 \pm 1.13$ \\
\hline $\mathrm{CP}$ & $18.5 \pm 1.02$ & $18.4 \pm 0.79$ \\
\hline NDIN & $0.82 \pm 0.03$ & $0.77 \pm 0.02$ \\
\hline ADIN & $0.43 \pm 0.04$ & $0.43 \pm 0.04$ \\
\hline NDF & $43.2 \pm 2.22$ & $44.3 \pm 1.61$ \\
\hline $\mathrm{ADF}$ & $28.2 \pm 1.33$ & $29.1 \pm 0.92$ \\
\hline Hemicellulose (NDF - ADF) & $15.0 \pm 1.30$ & $15.1 \pm 1.06$ \\
\hline Crude fat & $3.05 \pm 0.14$ & $2.81 \pm 0.16$ \\
\hline Ash & $7.82 \pm 0.24$ & $7.91 \pm 0.37$ \\
\hline \multicolumn{3}{|l|}{ NRC (2001) estimations ${ }^{8}$} \\
\hline RDP & 11.7 & 11.7 \\
\hline RUP & 6.80 & 6.69 \\
\hline MP-bacterial, g/d & 955 & 923 \\
\hline MP-RUP, g/d & 1,077 & 1,024 \\
\hline MP-endogenous, g/d & 89.6 & 86.3 \\
\hline MP supply, g/d & 2,121 & 2,033 \\
\hline RDP balance, g/d & 465 & 437 \\
\hline RUP balance, g/d & 365 & 336 \\
\hline MP balance, $\mathrm{g} / \mathrm{d}$ & 304 & 280 \\
\hline Lys, \% MP & 6.31 & 6.36 \\
\hline Met, \% MP & 1.61 & 1.62 \\
\hline His, $\% \mathrm{MP}$ & 2.01 & 2.02 \\
\hline Lys:Met ratio & 3.92 & 3.92 \\
\hline
\end{tabular}
soybean meal mix concentrate fed to mid-lactation dairy cows (\% DM, unless otherwise noted)

${ }^{1}$ p.m- and a.m.-cut TIM were analyzed individually in samples collected from d 15 to 21 in each period (n = 14 samples per treatment).

${ }^{2}$ The concentrate mix was composed (DM basis) of cracked corn (45.9\%), soybean meal $(47.1 \%)$, and a mineral plus vitamin premix $(6.98 \%)$.

${ }^{3} \mathrm{WSC}=$ water-soluble carbohydrates.

${ }^{4} \mathrm{HDP}$ fructans $=$ high-degree of polymerization fructans

${ }^{5}$ Analyzed as glucose equivalent using $p$-hydroxybenzoic acid hydrazide after extraction with methanol-chloroform-water extraction (Blakeney and Mutton, 1980).

${ }^{6} \mathrm{TESC}=$ total ethanol soluble carbohydrates.

${ }^{7}$ Analyzed as glucose equivalent using oxidase-peroxidase after sample extraction with ethanol (Hall, 2000).

${ }^{8}$ Actual feed nutrient composition and animal variables were used (i.e., DMI, milk yield and composition, DIM, and $\mathrm{BW})$. 
where $Y_{i j k l}=$ the dependent variable, $\mu=$ the overall mean, $\mathrm{S}_{\mathrm{i}}=$ the mean effect of the ith crossover sequence group, $\mathrm{C}_{\mathrm{j}}(\mathrm{S})_{\mathrm{i}}=$ the mean effect of the jth cow nested within ith sequence, $T_{k}=$ the mean effect of kth treatment, $\mathrm{ST}_{\mathrm{ik}}=$ the interaction between ith crossover sequence group and kth treatment (same as period effect), $\mathrm{PAR}_{1}=$ the mean effect of the lth parity, $\mathrm{TPAR}_{\mathrm{kl}}$ $=$ the interaction between the $\mathrm{kth}$ treatment and lth parity, and $\varepsilon_{\mathrm{ijkl}}=$ the random residual variation. All terms were considered fixed except $\mathrm{C}_{\mathrm{j}}(\mathrm{S})_{\mathrm{i}}$ and $\varepsilon_{\mathrm{ijk} k}$, which were considered random. All reported values are least squares means. Differences between least squares means were reported only if the $F$-test for treatment was significant at $P \leq 0.05$. Trends were declared at $0.05<P \leq 0.10$. The parity and treatment $\times$ parity interaction terms were removed from the final model if $P \geq 0.25$.

The following model was fitted for variables (ruminal $\mathrm{pH}, \mathrm{NH}_{3}-\mathrm{N}$, and VFA) with repeated measures over time:

$$
\begin{gathered}
\mathrm{Y}_{\mathrm{ijk} k \mathrm{~m}}=\mu+\mathrm{S}_{\mathrm{i}}+\mathrm{C}_{\mathrm{j}}(\mathrm{S})_{\mathrm{i}}+\mathrm{T}_{\mathrm{k}}+\mathrm{ST}_{\mathrm{ik}}+\mathrm{PAR}_{\mathrm{l}} \\
+\mathrm{TPAR}_{\mathrm{kl}}+\varepsilon 1_{\mathrm{ijkl}}+\mathrm{H}_{\mathrm{m}}+\mathrm{TH}_{\mathrm{km}}+\varepsilon 2_{\mathrm{ijk} \mathrm{m}},
\end{gathered}
$$

where $\mathrm{Y}_{\mathrm{ijklm}}=$ the dependent variable, $\mu=$ the overall mean, $\mathrm{S}_{\mathrm{i}}=$ the mean effect of the ith crossover sequence group, $C_{j}(S)_{i}=$ the mean effect of the jth cow nested within ith sequence, $\mathrm{T}_{\mathrm{k}}=$ the mean effect of kth treat- ment, $\mathrm{ST}_{\mathrm{ik}}=$ the interaction between the ith crossover sequence group and kth treatment (same as period effect), $\mathrm{PAR}_{\mathrm{l}}=$ the mean effect lth parity, $\mathrm{TPAR}_{\mathrm{kl}}=$ the interaction between the kth treatment and lth parity, $\varepsilon 1_{\mathrm{ijk} k}=$ the whole-plot random residual variation, $\mathrm{H}_{\mathrm{m}}=$ the mean effect of the mth hour of sampling analyzed as repeated measures, $\mathrm{TH}_{\mathrm{km}}=$ the interaction between the kth treatment and mth hour of sampling, and $\varepsilon 2_{\mathrm{ijklm}}$ $=$ the subplot random residual variation. The spatial covariance structure with the lowest Bayesian information criterion was retained in the final model. The subject of the repeated measurements was defined as cow (sequence) and cow (sequence $\times$ treatment). All terms were considered fixed, except $\mathrm{C}_{\mathrm{j}}(\mathrm{S})_{\mathrm{i}}, \varepsilon 1_{\mathrm{ijk} k \mathrm{l}}$, and $\varepsilon 2_{\mathrm{ijk} k \mathrm{~m}}$, which were considered random. All reported values are least squares means. Differences between least squares means were reported only if the $F$-test for treatment was significant at $P \leq 0.05$. Trends were declared at $0.05<P \leq 0.10$. The interactions treatment $\times$ hour of sampling and treatment $\times$ parity, as well as the parity term, were removed from the final model if $P \geq 0.25$.

\section{RESULTS}

\section{Timothy and TMR Nutrient Composition}

Nutrient compositions of the baleages, silages, and concentrate are presented in Table 1. The use of pooled samples for compositional analysis precluded us from

Table 3. Amino acid concentrations (g/kg of DM) of p.m.-cut timothy TMR (p.m.-cut TIM) and a.m.-cut timothy TMR (a.m.-cut TIM), p.m.- and a.m.-cut timothy baleage, p.m.- and a.m.-cut timothy silage, and a corn-soybean meal mix concentrate fed to mid-lactation dairy cows

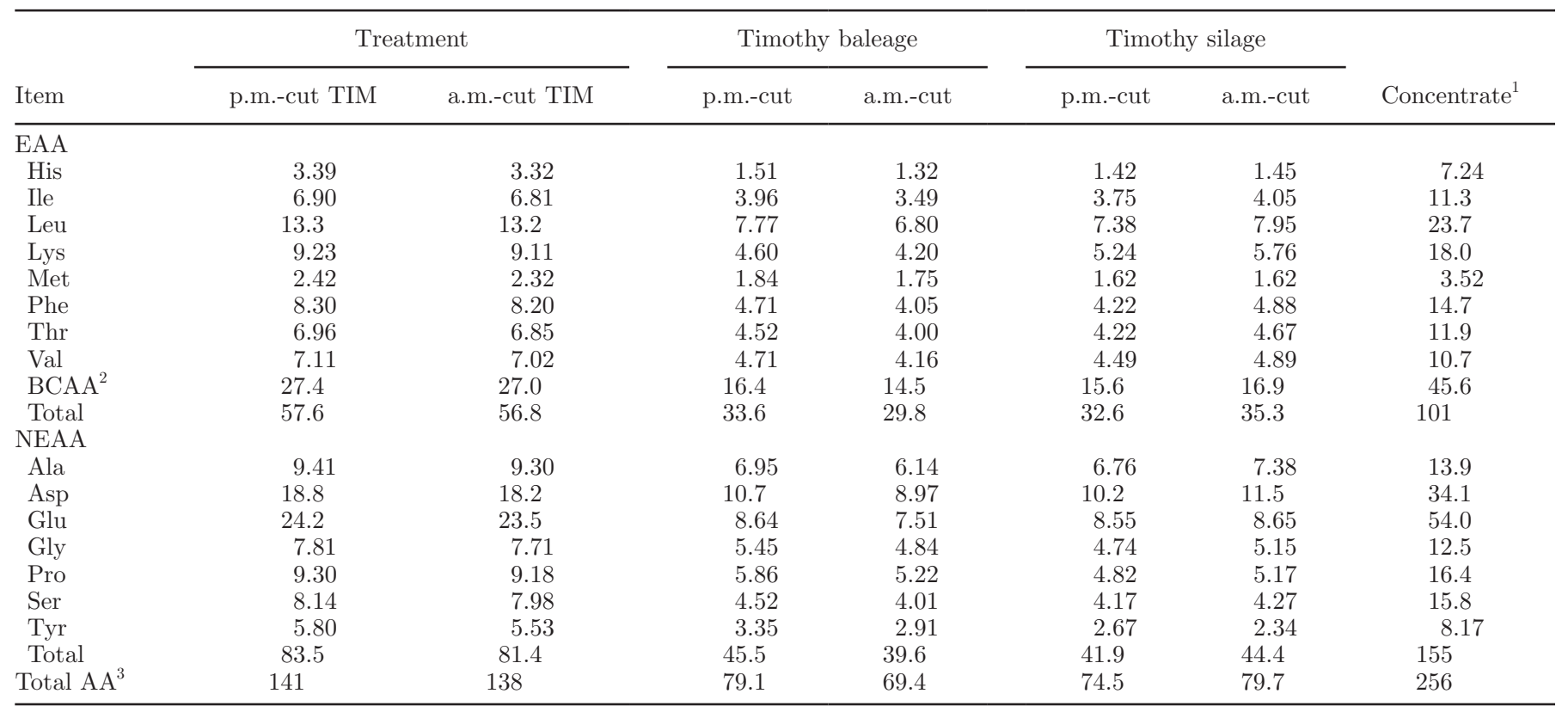

${ }^{1}$ The concentrate mix was composed (DM basis) of cracked corn (45.9\%), soybean meal (47.1\%), and a mineral plus vitamin premix (6.98\%).

${ }^{2} \mathrm{BCAA}=$ branched-chain AA.

${ }^{3}$ Total AA $=\mathrm{EAA}+$ NEAA. 
Table 4. Least squares means and SEM for variables with significant treatment $\times$ parity interactions in mid-lactation dairy cows fed TMR that consisted of p.m.-cut timothy baleage and silage (p.m.-cut TIM) or a.m.-cut timothy baleage and silage (a.m.-cut TIM) plus a corn-soybean meal mix concentrate

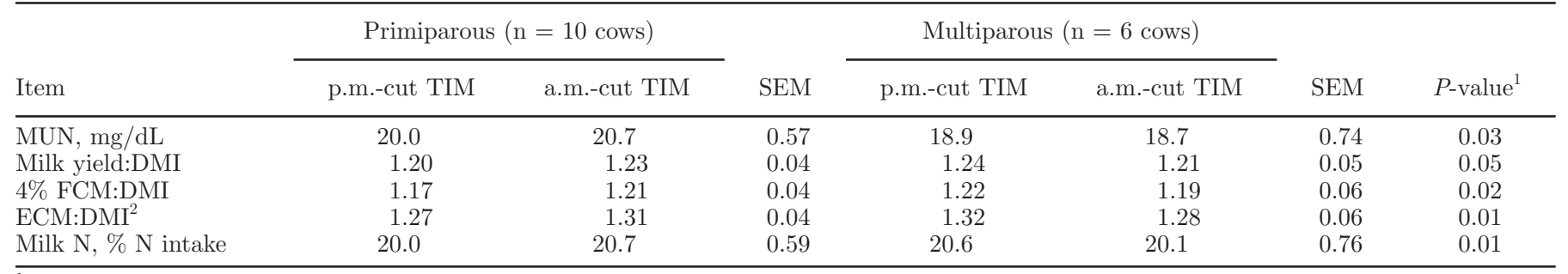

${ }^{1}$ Probability of treatment $\times$ parity effect; significance was declared at $P \leq 0.05$.

${ }^{2} \mathrm{ECM}=[0.327 \times$ milk yield $(\mathrm{kg} / \mathrm{d})]+[12.95 \times$ fat yield $(\mathrm{kg} / \mathrm{d})]+[7.2 \times$ protein yield $(\mathrm{kg} / \mathrm{d})] ;($ Orth, 1992$)$.

reporting a measurement of variation (e.g., SD) for the p.m.- and a.m.-cut baleages and silages in samples collected during each sampling period (d 15 to 21). However, we collected samples from individual bales $(\mathrm{n}=$ 42 /cutting time) before the beginning of the study and mean and SD values for the p.m.- and a.m.-cut timothy baleage NSC fractions were, respectively: $0.17 \pm 0.02 \%$ versus $0.13 \pm 0.03 \%$ (sucrose), $2.83 \pm 0.36 \%$ versus 2.64 $\pm 0.28 \%$ (glucose), $3.28 \pm 0.51 \%$ versus $2.68 \pm 0.36 \%$ (fructose), $6.28 \pm 0.83 \%$ versus $5.46 \pm 0.60 \%$ (WSC), $0.57 \pm 0.06 \%$ versus $0.48 \pm 0.04 \%$ (starch), and 6.85 $\pm 0.87 \%$ versus $5.93 \pm 0.62 \%$ (NSC). In addition, the concentrations $(\mathrm{n}=2 /$ cutting time) of total WSC $(6.53$ \pm 0.30 versus $5.48 \pm 0.43 \%)$, starch $(0.45 \pm 0.03 \%$ versus $0.40 \pm 0.02 \%)$, and NSC $(6.98 \pm 0.33$ versus 5.88 $\pm 0.45 \%)$ at ensiling were also numerically greater in the p.m.- versus a.m.-cut timothy silage, respectively.

Concentrations of sucrose, glucose, fructose, WSC, TESC, starch (using 2 analytical methods), and NSC in samples pooled over d 15 to 21 were all numerically greater in the p.m.- than in the a.m.-cut timothy baleage or silage. The concentration of HDP fructans was low and very similar across both timothy baleages, and HDP fructans were not detected in timothy silage. Whereas the concentration of $\mathrm{CP}$ was numerically greater in the p.m.- versus. a.m.-cut timothy baleage, p.m.-cut timothy silage had lower CP concentration than the a.m.-cut silage. Concentrations of NDF and ADF were numerically smallest in the p.m.-cut timothy baleage, whereas NDF concentration was slightly greater and $\mathrm{ADF}$ concentration slightly smaller when comparing p.m.- with a.m.-cut timothy silage. The fermentation profiles of both silages were relatively similar, but with the p.m.-cut showing slightly lower $\mathrm{pH}$ and concentrations of most organic acids (except isovalerate) and ethanol than the a.m.-cut. However, the concentration of lactic acid, as a proportion of total organic acids, was numerically greater in the p.m.versus a.m.-cut timothy silage (73.5 versus $68.9 \%$ ). Overall, the nutrient composition of the TMR (Table
2) followed the nutrient composition of the individual ingredients. For instance, the concentrations of WSC and NSC (WSC plus starch) were numerically greatest in the p.m.-cut TIM.

\section{Parity $\times$ Treatment Interactions and Parity Effects}

The parity $\times$ treatment interactions were significant for some of the measured variables (Table 4). Concentration of MUN was greatest $(P=0.03)$ for primiparous cows fed a.m.-cut TIM, but lowest in multiparous cows fed the same diet. Efficiencies expressed as milk yield:DMI $(P=0.05), 4 \%$ FCM:DMI $(P=0.02)$, ECM:DMI $(P=0.01)$, or milk $\mathrm{N}$ output:N intake $(P$ $=0.01)$ were greatest in primiparous cows fed a.m.-cut TIM and multiparous cows fed p.m.-cut TIM.

Parity also significantly affected some of the measured variables (Table 5). Intakes of nutrients, yields of milk and milk fat and protein, $4 \%$ FCM, and ECM were smallest $(P \leq 0.05)$ in primiparous cows. Similarly, plasma concentrations of Ile, Leu, Phe, Trp, and Val, as well as branched-chain AA (BCAA) and total EAA were smallest $(P \leq 0.04)$ in primiparous cows (Table 5$)$. On the other hand, the plasma concentrations of Ala, Asp, Ser, and total NEAA were greatest $(P \leq 0.05)$ in primiparous cows (Table 5).

\section{Ruminal Fermentation Profiles}

Ruminal $\mathrm{pH}$ did not differ significantly across treatments and averaged 6.28 (Table 6 ). With the exception of valerate, whose proportion was smallest $(P=0.02)$ with p.m.-cut TIM, no other significant changes were observed between treatments including total concentration of VFA (mean $=118 \mathrm{mM}$ ) and the ruminal molar proportions of propionate $($ mean $=17.8 \mathrm{~mol} / 100$ mol $)$, butyrate $($ mean $=9.08 \mathrm{~mol} / 100 \mathrm{~mol})$, isobutyrate $($ mean $=1.08 \mathrm{~mol} / 100 \mathrm{~mol})$, and isovalerate $($ mean $=$ $1.44 \mathrm{~mol} / 100 \mathrm{~mol}$; Table 6). The acetate-to-propionate ratio $($ mean $=3.97)$ also did not differ significantly in 
Table 5. Least squares means and SEM for variables with significant parity effects in mid-lactation dairy cows fed TMR that consisted of p.m.- or a.m.-cut timothy baleage and silage plus a corn-soybean meal mix concentrate

\begin{tabular}{|c|c|c|c|}
\hline \multirow[b]{2}{*}{ Item } & \multicolumn{2}{|c|}{ Parity } & \multirow[b]{2}{*}{$P$-value ${ }^{1}$} \\
\hline & $\begin{array}{l}\text { Primiparous } \\
(\mathrm{n}=10 \text { cows })\end{array}$ & $\begin{array}{l}\text { Multiparous } \\
(\mathrm{n}=6 \text { cows })\end{array}$ & \\
\hline DMI, kg/d & $17.6 \pm 0.62$ & $20.3 \pm 0.80$ & 0.02 \\
\hline $\mathrm{N}$ intake, $\mathrm{g} / \mathrm{d}$ & $538 \pm 18.4$ & $619 \pm 23.8$ & 0.02 \\
\hline $\mathrm{NSC}_{\text {intake }}^{2}, \mathrm{~kg} / \mathrm{d}$ & $2.23 \pm 0.07$ & $2.58 \pm 0.10$ & 0.02 \\
\hline $\mathrm{NSC}$ intake ${ }^{3}, \mathrm{~kg} / \mathrm{d}$ & $2.28 \pm 0.08$ & $2.64 \pm 0.10$ & 0.02 \\
\hline OM intake, $\mathrm{kg} / \mathrm{d}$ & $16.3 \pm 0.57$ & $18.8 \pm 0.74$ & 0.02 \\
\hline NDF intake, $\mathrm{kg} / \mathrm{d}$ & $7.42 \pm 0.27$ & $8.58 \pm 0.35$ & 0.02 \\
\hline $\mathrm{ADF}$ intake, $\mathrm{kg} / \mathrm{d}$ & $4.90 \pm 0.18$ & $5.64 \pm 0.23$ & 0.02 \\
\hline Milk yield, kg/d & $21.2 \pm 1.01$ & $25.0 \pm 1.30$ & 0.04 \\
\hline $4 \%$ FCM, kg/d & $20.7 \pm 1.04$ & $24.6 \pm 1.34$ & 0.04 \\
\hline $\mathrm{ECM}, \mathrm{kg} / \mathrm{d}$ & $22.5 \pm 1.09$ & $26.6 \pm 1.41$ & 0.04 \\
\hline Milk fat, $\mathrm{kg} / \mathrm{d}$ & $0.82 \pm 0.05$ & $0.97 \pm 0.06$ & 0.05 \\
\hline Milk protein, $\mathrm{kg} / \mathrm{d}$ & $0.69 \pm 0.03$ & $0.81 \pm 0.04$ & 0.04 \\
\hline Plasma Ile, $\mu M$ & $113 \pm 4.54$ & $130 \pm 5.86$ & 0.04 \\
\hline Plasma Leu, $\mu M$ & $115 \pm 5.12$ & $148 \pm 6.61$ & $<0.01$ \\
\hline Plasma Phe, $\mu M$ & $41.6 \pm 1.33$ & $47.6 \pm 1.72$ & 0.02 \\
\hline Plasma Trp, $\mu M$ & $36.7 \pm 1.02$ & $41.3 \pm 1.32$ & 0.02 \\
\hline Plasma Val, $\mu M$ & $208 \pm 10.1$ & $256 \pm 13.0$ & 0.01 \\
\hline Plasma Ala, $\mu M$ & $234 \pm 9.20$ & $201 \pm 11.9$ & 0.04 \\
\hline Plasma Asp, $\mu M$ & $25.6 \pm 1.68$ & $20.5 \pm 1.30$ & 0.03 \\
\hline Plasma Ser, $\mu M$ & $65.7 \pm 2.32$ & $57.5 \pm 3.00$ & 0.05 \\
\hline Plasma BCAA, $\mu M$ & $436 \pm 19.2$ & $534 \pm 24.7$ & $<0.01$ \\
\hline Plasma EAA, $\mu M$ & $750 \pm 25.1$ & $872 \pm 32.4$ & 0.01 \\
\hline Plasma NEAA, $\mu M$ & $1,127 \pm 27.7$ & $1,030 \pm 35.7$ & 0.05 \\
\hline
\end{tabular}

${ }^{1}$ Probability of parity effect; significance was declared at $P \leq 0.05$.

${ }^{2} \mathrm{NSC}=$ water soluble carbohydrates + starch.

${ }^{3} \mathrm{NSC}=$ total ethanol soluble carbohydrates + starch.

cows fed p.m.- or a.m.-cut TIM (Table 6). However, treatment $\times$ sampling time interactions were observed for the ruminal concentration of $\mathrm{NH}_{3}-\mathrm{N}(P<0.001$; Figure 1a) and the molar proportion of acetate $(P<$ 0.01; Figure 1b). Compared with cows fed a.m.-cut TIM, the ruminal concentrations of $\mathrm{NH}_{3}-\mathrm{N}$ were lower at $1100(P<0.01)$ and $1200 \mathrm{~h}(P=0.02)$ and greater at $1800 \mathrm{~h}(P=0.02)$. Cows fed p.m.-cut TIM had greater
$(P=0.05)$ ruminal molar proportion of acetate at 0800 $h$ than those fed a.m.-cut TIM.

\section{Animal Performance and Plasma Concentrations of Amino Acids}

Intakes of DM $(P=0.02 ;+0.7 \mathrm{~kg} / \mathrm{d}), \mathrm{N}(P<0.01$; $+29 \mathrm{~g} / \mathrm{d}), \mathrm{NSC}(P<0.001 ;+0.25 \mathrm{~kg} / \mathrm{d})$, and $\mathrm{OM}(P$

Table 6. Effects of feeding TMR that consisted of p.m.-cut timothy baleage and silage (p.m.-cut TIM) or a.m.-cut timothy baleage and silage (a.m.-cut TIM) plus a corn-soybean meal mix concentrate on the ruminal fermentation profile in mid-lactation dairy cows $(\mathrm{n}=8$ cows; 2 primiparous and 6 multiparous $)$

\begin{tabular}{lcccc}
\hline \multicolumn{2}{c}{ Treatment } & & \\
\cline { 2 - 3 } Item & p.m.-cut TIM & a.m.-cut TIM & SEM & $P_{\text {-value }}^{1}$ \\
\hline $\mathrm{pH}$ & 6.26 & 6.29 & 0.05 & 0.50 \\
$\mathrm{NH}_{3}-\mathrm{N}, \mathrm{mg} / \mathrm{dL}$ & 18.0 & 19.0 & 0.67 & 0.11 \\
Total VFA, mM & 116 & 119 & 4.35 & 0.16 \\
VFA, mol/100 mol & & & & \\
Acetate (A) & 69.6 & 69.7 & 0.64 & 0.79 \\
Propionate (P) & 17.8 & 18.0 & 0.53 & 0.59 \\
Butyrate & 9.45 & 9.09 & 0.27 & 0.21 \\
Isobutyrate & 1.04 & 1.11 & 0.07 & 0.19 \\
Valerate & 1.01 & 1.17 & 0.06 & 0.02 \\
Isovalerate & 1.46 & 1.58 & 0.11 & 0.22 \\
A:P ratio & 3.96 & 3.97 & 0.13 & 0.89 \\
\hline
\end{tabular}

${ }^{1}$ Probability of treatment effect (p.m.- vs. a.m.-cut timothy TMR); significance was declared at $P \leq 0.05$ and trends at $0.05<P \leq 0.10$. 


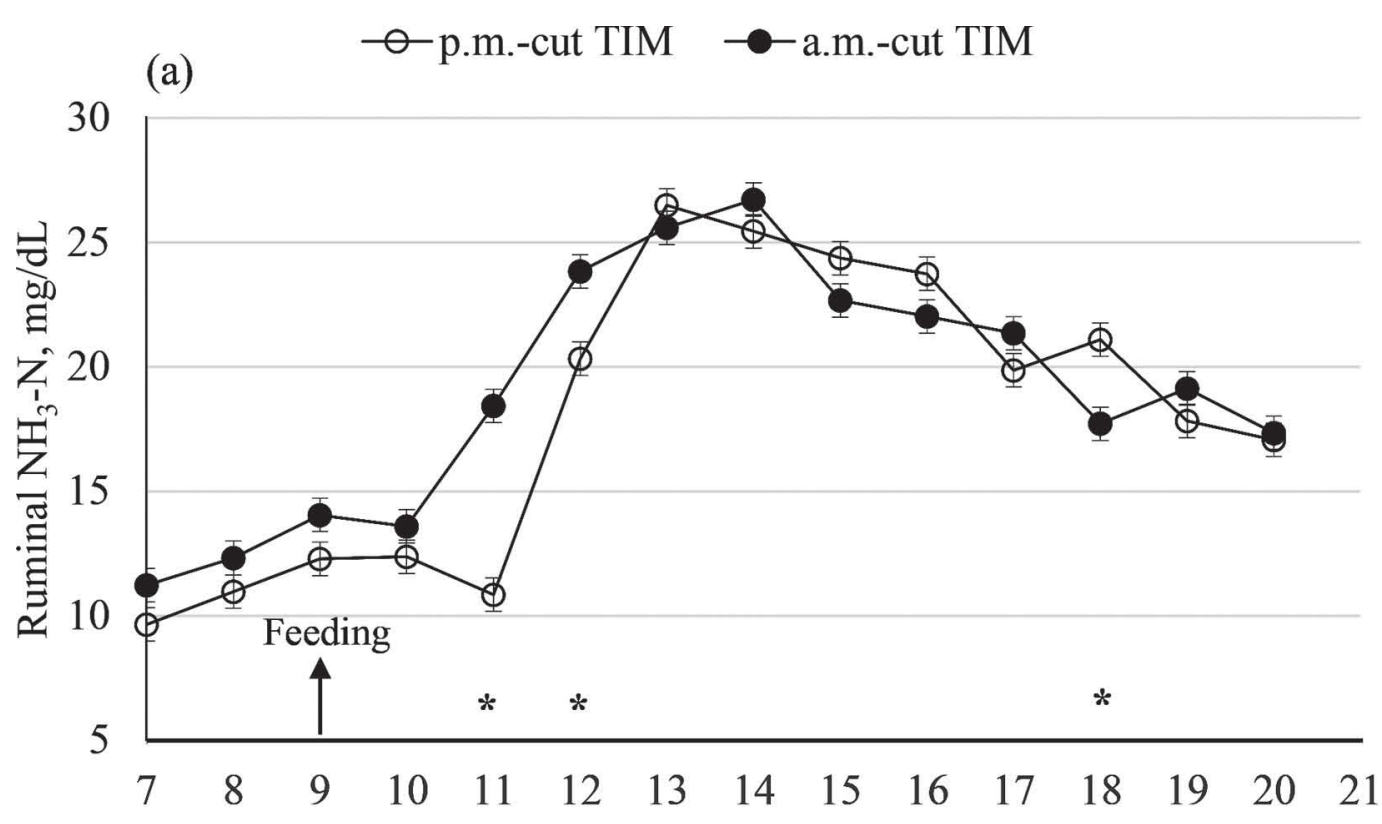

(b)

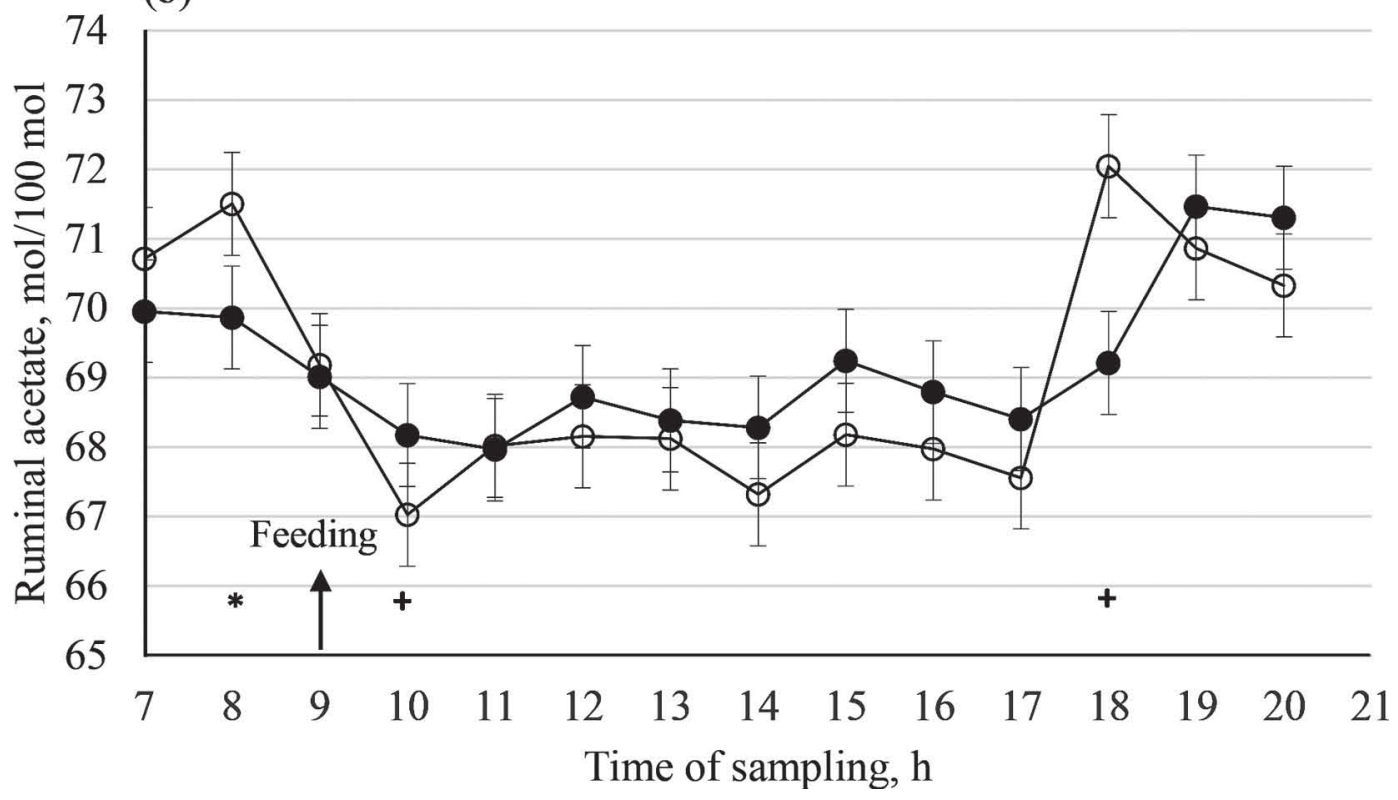

Figure 1. Diurnal variation in the ruminal concentration of $\mathrm{NH}_{3}-\mathrm{N}$ (a) and molar proportion of acetate (b) in lactating dairy cows cows (n $=8 ; 2$ primiparous and 6 multiparous) fed TMR that consisted of p.m.-cut timothy baleage and silage (p.m.-cut TIM) or a.m.-cut timothy baleage and silage (a.m.-cut TIM) plus a corn-soybean meal mix concentrate; $\mathrm{SEM}= \pm 0.67 \mathrm{mg} / \mathrm{dL}\left(\mathrm{NH}_{3}-\mathrm{N}\right)$ and $\pm 0.74 \mathrm{~mol} / 100 \mathrm{~mol}($ acetate). A significant treatment $\times$ sampling time interaction $(P<0.001)$ was observed for ruminal $\mathrm{NH}_{3}-\mathrm{N}$, and differences $(*)$ between treatments at each sampling time were found at $1100 \mathrm{~h}(P<0.01), 1200 \mathrm{~h}(P=0.02)$, and $1800 \mathrm{~h}(P=0.02)$. A significant treatment $\times$ sampling time interaction $(P<0.01)$ was observed for ruminal acetate, and a difference $\left(^{*}\right)$ between treatments was found at $0800 \mathrm{~h}(P=0.05)$, whereas trends $(+)$ were found at $1000 \mathrm{~h}(P=0.07)$ and $1800 \mathrm{~h}(P=0.09)$. Cows were fed at $0900 \mathrm{~h}$ as indicated by the arrow in the figure. Spot ruminal samples were collected over the course of $3 \mathrm{~d}$ (d 15 to 17$)$.

$=0.01 ;+0.6 \mathrm{~kg} / \mathrm{d})$ were greatest in cows fed p.m.-cut TIM (Table 7). Similarly, DMI, expressed as a proportion of BW, was greatest with feeding p.m.- rather than a.m.-cut TIM (3.19 vs. $3.06 \%$ of BW, respectively; $P<$ 0.01). No significant treatment effects were observed for intakes of NDF and ADF, which averaged 8.01 and 5.28 $\mathrm{kg} / \mathrm{d}$, respectively (Table 7 ). Whereas milk yield tended to increase $(P=0.10 ;+0.8 \mathrm{~kg} / \mathrm{d})$, both $(P=0.02 ;+0.9$ $\mathrm{kg} / \mathrm{d}) 4 \%$ FCM and ECM were greatest with feeding p.m.-cut TIM (Table 7). Concentrations of milk fat 
$($ mean $=3.87 \%)$, protein $($ mean $=3.26 \%)$, and lactose $($ mean $=4.43 \%)$ were not affected by feeding p.m.- or a.m.-cut TIM. On the other hand, yields of milk fat $(P$ $=0.01 ;+30 \mathrm{~g} / \mathrm{d})$, protein $(P=0.03 ;+40 \mathrm{~g} / \mathrm{d})$, and lactose $(P=0.06 ;+50 \mathrm{~g} / \mathrm{d})$ were greatest in cows fed p.m.-cut TIM (Table 7). Concentrations of plasma urea $\mathrm{N}($ mean $=22.3 \mathrm{mg} / \mathrm{dL})$ and plasma NEFA $($ mean $=$ $86.1 \mathrm{mEq} / \mathrm{L})$, and ADG (mean $=0.51 \mathrm{~kg} / \mathrm{d}$ ) were not significantly affected by treatments (Table 7). Except for the plasma concentration of Gly, which was greatest $(P=0.05)$ with feeding a.m.-cut TIM, the plasma concentrations of the remaining individual EAA and NEAA, BCAA, total EAA, total NEAA, and total AA (EAA plus NEAA) were not affected by treatments (Table 8).

\section{DISCUSSION}

\section{Nutrient Composition of Timothy Baleage and Silage}

Shifting cutting from morning to afternoon numerically increased the concentrations of individual sugars such as sucrose $(+50 \%)$, glucose $(+30 \%)$, and fructose
$(+46 \%)$ in timothy baleage. Previous studies conducted with fresh timothy cut at p.m. rather than a.m. also led to increased concentrations of sucrose, glucose, and fructose (Bertrand et al., 2008; Pelletier et al., 2009, 2010; Morin et al., 2012). The concentration of starch, measured using 2 different analytical methods, was numerically greater in the p.m.- compared with a.m.cut timothy baleage. However, the difference in starch concentration in response to cutting time was much smaller than that observed for individual sugars, which agrees with Bertrand et al. (2008) and Pelletier et al. (2009, 2010). On the other hand, cutting time barely affected the concentration of HDP fructans of both baleage sources in the present study. Our results agreed with Bertrand et al. (2008) and Pelletier et al. (2009, 2010) who reported no effect of cutting time on the concentration of HDP fructans in fresh timothy. Fisher et al. (1999) also reported no effect of cutting time on the concentration of fructans in tall fescue hay. It is worth noting that the concentration of HDP fructans has been shown to be highly variable (from 0 to $5.49 \%$ DM) and affected by plant species and growth period (i.e., spring growth versus summer regrowth; Pelletier

Table 7. Effects of feeding TMR that consisted of p.m.-cut timothy baleage and silage (p.m.-cut TIM) or a.m.-cut timothy baleage and silage (a.m.-cut TIM) plus a corn-soybean meal mix concentrate on nutrient intake, milk yield, concentrations and yields of milk components, plasma concentrations of urea N (PUN) and nonesterified fatty acids (NEFA), and ADG in mid-lactation dairy cows ( $\mathrm{n}=16$ cows; 10 primiparous and 6 multiparous)

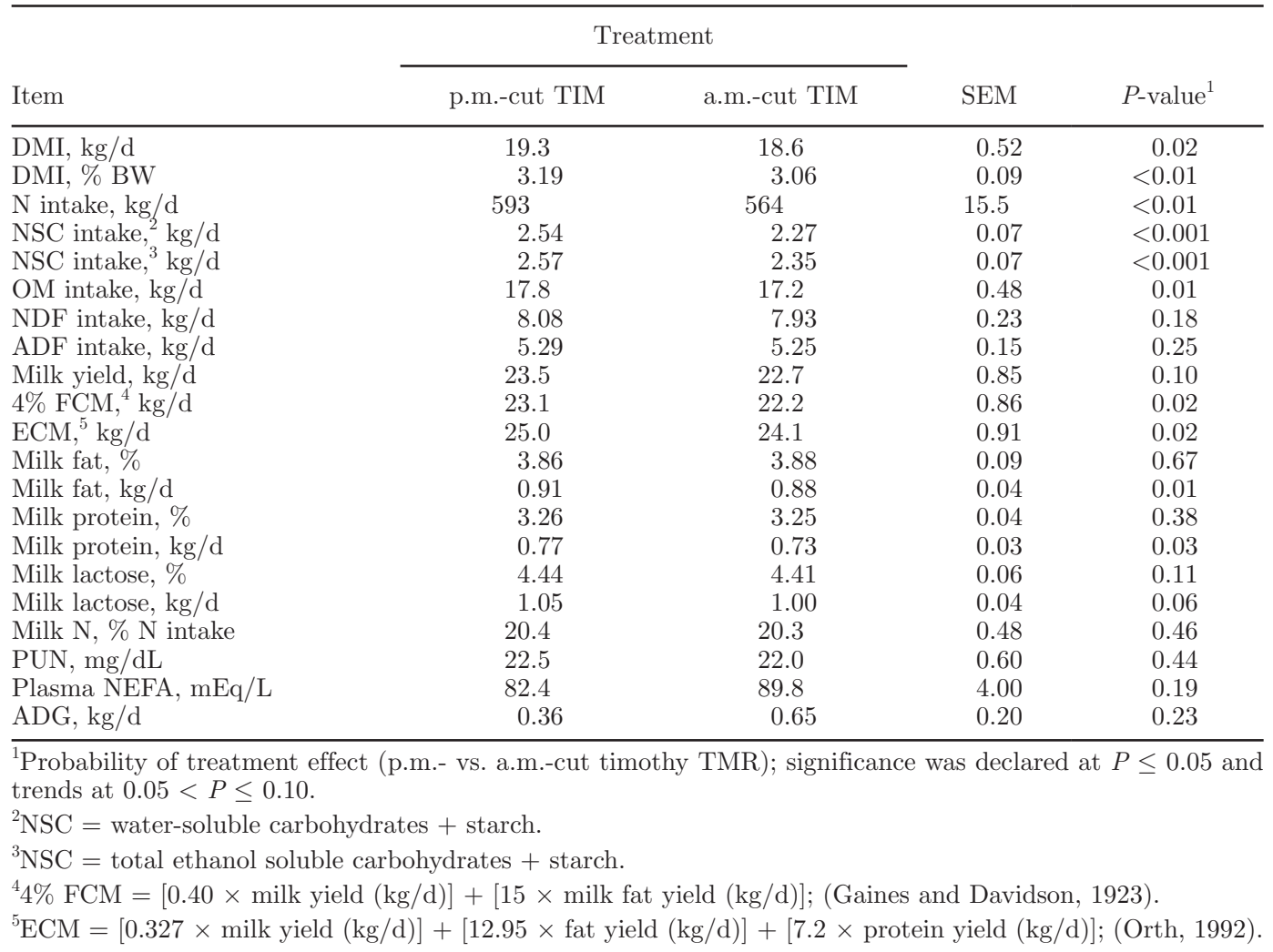


et al., 2010), as well as stage of plant development (i.e., heading versus anthesis; Pelletier et al., 2009).

The concentrations of NSC calculated by adding WSC plus starch $(+35 \%)$ or TESC plus starch $(+24 \%)$ were numerically greater in the p.m.- versus a.m.-cut timothy baleage. Mean increases in NSC concentrations ranged from +12 to $+137 \%$ in fresh timothy harvested in the afternoon than in the morning (Bertrand et al., 2008; Pelletier et al., 2009, 2010; Morin et al., 2012). We are not aware of any study that investigated the effect of diurnal cutting management on NSC concentration of timothy baleage. However, positive effects of cutting time on NSC concentrations of tall fescue hay (Fisher et al., 1999), and gamagrass and switchgrass baleage (Huntington and Burns, 2007) have been reported. Specifically, Fisher et al. (1999) observed increases ranging from 22 to $31 \%$ in the mean concentrations of monosaccharides, disaccharides, and NSC in p.m.- versus a.m.-cut tall fescue hay. Compared with a.m.-cut gamagrass and switchgrass baleage, the p.m.cuts had greater concentrations of monosaccharides (1.71 versus $1.12 \%)$, starch (0.93 versus $0.47 \%)$, and NSC (3.04 versus 1.90\%) according to Huntington and
Burns (2007). Overall, both the mean increase in NSC concentration and the actual NSC value of the p.m.-cut timothy baleage in the present study were within the range reported in the literature for fresh timothy (Bertrand et al., 2008; Pelletier et al., 2009, 2010; Morin et al., 2012) and other grasses (e.g., tall fescue hay, and gamagrass and switchgrass baleages). Collectively, these results suggest that preserving timothy herbage as heavily wilted baleage minimized NSC losses during storage.

Although the concentrations of individual sugars, starch, and NSC were numerically greater in the p.m.than a.m.-cut timothy silage, these values were much lower than those observed for the p.m.-cut baleage indicating potentially large NSC losses during silage fermentation. Research conducted with silages of red clover (Owens et al., 2002) and alfalfa (Tremblay et al., 2014) cut in the afternoon and preserved in laboratory silos showed marked reductions in the concentrations of WSC and NSC as a result of fermentation processes during storage. We are not aware of any studies that investigated the effects of diurnal cutting management on NSC concentration of timothy silage. However, pre-

Table 8. Effects of feeding TMR that consisted of p.m.-cut timothy baleage and silage (p.m.-cut TIM) or a.m.-cut timothy baleage and silage (a.m.-cut TIM) plus a corn-soybean meal mix concentrate on the plasma concentrations $(\mu M)$ of AA in mid-lactation dairy cows ( $\mathrm{n}=16$ cows; 10 primiparous and 6 multiparous)

\begin{tabular}{|c|c|c|c|c|}
\hline \multirow[b]{2}{*}{ Item } & \multicolumn{2}{|c|}{ Treatment } & \multirow[b]{2}{*}{ SEM } & \multirow[b]{2}{*}{$P$-value ${ }^{1}$} \\
\hline & p.m.-cut TIM & a.m.-cut TIM & & \\
\hline \multicolumn{5}{|l|}{ EAA } \\
\hline His & 50.2 & 47.7 & 2.70 & 0.40 \\
\hline Ile & 120.2 & 123.3 & 5.14 & 0.67 \\
\hline Leu & 132 & 132 & 5.91 & 0.99 \\
\hline Lys & 72.2 & 74.2 & 3.73 & 0.71 \\
\hline Met & 20.6 & 21.8 & 0.93 & 0.32 \\
\hline Phe & 43.6 & 45.7 & 1.52 & 0.25 \\
\hline Thr & 95.9 & 102 & 5.43 & 0.25 \\
\hline Trp & 38.3 & 39.7 & 1.15 & 0.32 \\
\hline Val & 234 & 230 & 9.35 & 0.64 \\
\hline $\mathrm{BCAA}^{2}$ & 486 & 485 & 19.7 & 0.97 \\
\hline Total & 807 & 816 & 29.0 & 0.83 \\
\hline \multicolumn{5}{|l|}{ NEAA } \\
\hline Ala & 213 & 222 & 8.25 & 0.26 \\
\hline Asn & 41.7 & 42.8 & 1.63 & 0.44 \\
\hline Asp & 22.3 & 23.9 & 1.27 & 0.38 \\
\hline Cys & 97.3 & 95.6 & 1.93 & 0.66 \\
\hline Gln & 292 & 300 & 12.3 & 0.33 \\
\hline Glu & 45.2 & 44.4 & 1.38 & 0.51 \\
\hline Gly & 172 & 188 & 6.41 & 0.05 \\
\hline Pro & 69.1 & 69.2 & 2.32 & 0.87 \\
\hline Ser & 61.3 & 62.0 & 2.46 & 0.66 \\
\hline Tyr & 46.7 & 49.1 & 2.71 & 0.46 \\
\hline Total & 1,060 & 1,097 & 26.3 & 0.16 \\
\hline Total $\mathrm{AA}^{3}$ & 1,866 & 1,913 & 44.9 & 0.33 \\
\hline
\end{tabular}

${ }^{1}$ Probability of treatment effect (p.m.- vs. a.m.-cut timothy TMR); significance was declared at $P \leq 0.05$ and trends at $0.05<P \leq 0.10$.

${ }^{2} \mathrm{BCAA}=$ branched-chain AA.

${ }^{3}$ Total $\mathrm{AA}=\mathrm{EAA}+\mathrm{NEAA}$. 
vious studies have addressed the effects of restricting silage fermentation with formic acid on timothy silage quality and fermentation characteristics (e.g., Narasimhalu et al., 1992; Hetta et al., 2003; Martineau et al., 2007). Compared with the formic acid-treated timothy silage, the concentration of WSC was reduced by 8 -fold in the untreated timothy silage, averaging $0.52 \%$ (Hetta et al., 2003), which is similar to the WSC concentration observed in our timothy silage fed during the 42-d study. Overall, both timothy silages used in our study were of good quality based on a dominant lactic acid fermentation (i.e., low $\mathrm{pH}$ and low concentrations of butyric acid, acetic acid, and ethanol).

\section{Parity $\times$ Treatment Interactions and Parity Effects}

A parity $\times$ treatment interaction was observed for MUN with primiparous and multiparous cows fed a.m.cut TIM showing the greatest and smallest concentrations, respectively. It is difficult to explain this effect because the concentration of $\mathrm{CP}$ was slightly lower in the a.m.- compared with the p.m.-cut TIM. Parity $\times$ treatment interactions were also observed for feed and milk $\mathrm{N}$ efficiency. For instance, the difference in DMI $(+0.8 \mathrm{~kg} / \mathrm{d} ; 18.0$ versus $17.2 \mathrm{~kg} / \mathrm{d}$; data not shown $)$ in primiparous cows fed p.m.- versus a.m.-cut TIM was larger than that in milk yield $(+0.4 \mathrm{~kg} / \mathrm{d} ; 21.4$ versus $20.0 \mathrm{~kg} / \mathrm{d}$; data not shown). Conversely, the difference in DMI $(+0.6 \mathrm{~kg} / \mathrm{d} ; 20.7$ versus $20.0 \mathrm{~kg} / \mathrm{d}$; data not shown) in multiparous cows fed p.m.- versus a.m.-cut TIM was smaller than that in milk yield $(+1.3 \mathrm{~kg} / \mathrm{d}$; 25.7 versus $24.3 \mathrm{~kg} / \mathrm{d}$; data not shown). Collectively, these results explained the interactions in feed and milk $\mathrm{N}$ efficiency observed in the present experiment. However, the underline treatment effects and biological mechanisms regulating these interactions are not clear.

As expected, intakes of nutrients, yields of milk and milk fat and protein, 4\% FCM, and ECM were all lower in primiparous than in multiparous cows. Primiparous cows had the lowest plasma concentrations of Ile, Leu, Phe, Trp, Val, BCAA, and total EAA, and greatest plasma concentrations of Ala, Asp, Ser, and total NEAA. Recently, Patton et al. (2015) demonstrated, using a meta-analytical approach, that only the plasma concentration of Arg was affected by parity with primiparous cows showing greater concentrations of Arg than multiparous cows. Patton et al. (2015) hypothesized that the lower milk yield in primiparous compared with older cows, associated with the apparent high demand of Arg for milk synthesis (Lapierre et al., 2012), likely explained their results. Even though the plasma concentration of Arg was not measured in the current study, our data showed that the plasma concen- trations of several EAA including BCAA were smallest in primiparous cows, suggesting high EAA demand to meet growth requirements. According to Patton et al. (2015), demand of EAA for growth requirements combined with lower DMI and microbial protein synthesis would likely exacerbate EAA deficiencies in primiparous cows.

\section{Ruminal Fermentation Profiles}

The lack of dietary effect on most of the ruminal fermentation variables is not surprising because differences in DMI and NSC intake were modest across treatments. Small differences in DMI and NSC intake also resulted in minor changes in the ruminal fermentation profiles in early-lactation dairy cows fed a diet containing high- or low-NSC alfalfa baleage (Brito et al., 2014). The observed treatment $\times$ sampling time interactions (Figure 1) for the ruminal concentration of $\mathrm{NH}_{3}-\mathrm{N}$ and ruminal molar proportion of acetate are difficult to explain. However, differences in feeding behavior (e.g., TMR consumption rate) or ruminal NSC degradability or both could partially explain these interactions. For instance, beef steers fed p.m.- rather than a.m.-cut switchgrass or gamagrass baleage spent significantly more time eating and less time resting during meals (Huntington and Burns, 2007). Fisher et al. (1999) reported greater rate of DMI in small ruminants fed p.m.- versus a.m.-cut tall fescue hays, but not in beef steers. Gregorini et al. (2006, 2008) reported longer and more intense grazing bouts in beef cattle grazing pasture in the afternoon than in the morning. In addition to feeding behavior, Yari et al. (2012) showed that the effective degradability of total carbohydrates in the rumen tended to be greater with p.m.- rather than a.m.-cut alfalfa hay, which may explain the reduced concentration of ruminal $\mathrm{NH}_{3}-\mathrm{N}$ at 2 and $3 \mathrm{~h}$ after feeding with p.m.-cut TIM.

\section{Animal Performance and Plasma Concentrations of Amino Acids}

Intake of DM was greatest with feeding p.m.-cut TIM, which may be explained by increased animal preference for the p.m.-cut timothy baleage over its a.m.-cut counterpart. Similarly, DMI, expressed as a proportion of BW, was greatest in cows fed p.m.-cut TIM, thus indicating that BW had no impact on the effect of p.m. harvesting on DMI. Compared with a.m.-cut, p.m.-cut tall fescue hay was preferred by sheep, goats, and beef steers in all experiments conducted by Fisher et al. (1999). Smit et al. (2006) reported that grazing dairy cows preferentially selected perennial ryegrass (Lolium 
perenne L.) cultivars with high concentration of WSC (range from 13.5 to $16.5 \%$ ). Beef heifers also preferred tall fescue pasture with increased concentration of NSC (range from 10.8 to $13.8 \%$; Mayland et al., 2000). It appears that increased forage NSC concentration is positively associated with feed intake. For instance, Fisher et al. (1999) observed greatest short-term DMI (g/meal) in sheep, goats, and beef steers fed p.m.-cut tall fescue hays. Huntington and Burns (2007) also demonstrated that p.m. harvesting resulted in enhanced concentration of NSC in gamagrass and switchgrass baleages, which in turn led to increased voluntary intake in beef steers.

Milk yield tended to increase $(+3.5 \%)$, whereas $4 \%$ FCM $(+4.1 \%)$ and ECM $(+3.7 \%)$ significantly increased in cows fed p.m.-cut TIM with these results primarily explained by enhanced DMI $(+3.8 \%)$ and NSC intake $(+9.4$ to $+10.5 \%)$. Increased dietary NSC concentration also resulted in comparable increases in DMI $(+4.7 \%)$, milk yield $(+4.7 \%), 4 \%$ FCM $(+8.0 \%)$, and $\operatorname{ECM}(+7.9 \%)$ in late-lactation dairy cows fed p.m.- versus a.m.-cut alfalfa baleage as the sole feed source (Brito et al., 2008). Pagano et al. (2011) observed significant increases in DMI $(+21 \%)$ and milk yield $(+10.8 \%)$ in dairy goats fed freshly cut p.m. or a.m. berseem clover (Trifolium alexandrinum L.). Milk yield $(+2.7 \mathrm{~kg} / \mathrm{d})$ also increased in late-lactation dairy cows fed a freshly cut perennial ryegrass variety rich in WSC compared with a traditional counterpart (Miller et al., 2001). In all these studies that reported increased milk yield, no concentrate (Brito et al., 2008) or up to $34 \%$ of concentrate (current study) was included in the diet. However, when a greater proportion of concentrate was used (ranging from $47 \%$ to $65 \%$ of diet DM), milk yield was not improved in response to high-NSC alfalfa baleage (Brito et al., 2014) or p.m.-cut alfalfa hay (Yari et al., 2014) fed to dairy cows. It is conceivable that the amount of concentrate fed in the studies of Brito et al. (2014) and Yari et al. (2014) provided enough ruminally fermentable energy to meet both microbial and animal requirements, thus diluting the contribution of forage NSC to total dietary NSC. In fact, Ellis et al. (2011) showed, using a dynamic mechanistic model, that milk yield was more responsive when dairy cows were fed high-WSC grass without grain supplementation than when $2 \mathrm{~kg} / \mathrm{d}$ of grain was supplemented.

We are not aware of any studies to date that investigated the effects of timothy diurnal cutting management on performance and milk composition in dairy cows. However, some studies have addressed the effects of restricting silage fermentation with formic acid on performance of lactating dairy cows fed timothymeadow fescue mix (e.g., Huhtanen et al., 1997), or timothy as the sole forage source (e.g., Martineau et al., 2007). Compared with extensively fermented timothy silage (i.e., treated with bacterial inoculant), formic acid-treated timothy silage averaged $138 \%$ more WSC (Huhtanen et al., 1997; Martineau et al., 2007). Although this difference in WSC was much larger than that found between p.m.- and a.m.-cut TIM, DMI and yields of milk and milk components did not differ significantly across treatments (Huhtanen et al., 1997; Martineau et al., 2007). It is important to note that a limited number of cows $(n=4)$ were used to obtain production data in the studies of Huhtanen et al. (1997) and Martineau et al. (2007). Therefore, their animal performance data and comparisons with the literature should be done cautiously. Further research is needed to elucidate discrepancies in performance of cows fed forage with increased NSC via diurnal cutting management or restricted fermentation strategies such as formic acid use.

The increases in milk yield, $4 \%$ FCM, and ECM with feeding p.m.-cut TIM in our study were relatively modest. According to Ellis et al. (2011), simulated milk yield decreased slightly when grass WSC increased at the expense of $\mathrm{CP}$, increased slightly when WSC increased at the expense of a 50:50 combination of $\mathrm{CP}$ and NDF, and increased most when WSC increased at the expense of NDF. The difference in NDF concentration between the p.m.- and a.m.-cut TIM was small (-1.1 percentage units) and helps explain the modest increase in milk yield $(+0.8 \mathrm{~kg} / \mathrm{d})$ as supported by the modeling work of Ellis et al. (2011). Both Miller et al. (2001) and Moorby et al. (2006) reported reductions in dietary NDF concentration ranging from 4.5 to 8.3 percentage units, which coincided with increases in milk yield ranging from 2.3 to $2.7 \mathrm{~kg} / \mathrm{d}$ in dairy cows fed a perennial ryegrass cultivar rich in WSC versus a traditional perennial ryegrass cultivar.

Only plasma Gly was affected by cutting time, with the smallest concentration observed in cows fed p.m.cut TIM. It is not clear why Gly was decreased, but its lower plasma concentration suggests a larger removal by hepatic tissues. Blouin et al. (2002) reported that, among all AA analyzed, only Gly was affected by MP supply with cows fed the high-MP diet showing a greater hepatic net removal of Gly than those fed the low-MP diet. It is important to note, however, that the difference in MP supply between the high- and lowMP diets in the experiment of Blouin et al. (2002) was 3 -fold greater than that between the p.m.- and a.m.-cut TIM (Table 2). Overall, results from the current study and those from Brito et al. $(2008,2014)$ showed minor effects of increased forage NSC on plasma concentrations of AA. 


\section{CONCLUSIONS}

Shifting cutting from morning to afternoon increased the concentrations of NSC in timothy baleage (mean = $+27 \%$ ) and silage $($ mean $=+30 \%)$. However, the NSC concentrations of timothy silages were much lower than those of timothy baleages likely as a result of extensive fermentation during storage. The parity $\times$ treatment interactions observed for MUN, milk N efficiency, and feed efficiency preclude any general conclusion about the effect of timothy diurnal cutting management on $\mathrm{N}$ use and feed conversion efficiency in dairy cows. The treatment $\times$ sampling time interaction observed for the ruminal concentration of $\mathrm{NH}_{3}-\mathrm{N}$ suggests that p.m.-cut TIM elicited changes in feeding behavior or forage carbohydrate degradation kinetics or both. Parity effects were observed for the plasma concentrations of Ile, Leu, Phe, Trp, and Val with primiparous cows showing the smallest values, which suggest a high demand for EAA to meet growth requirements. Even though the intake of NSC was greatest in cows fed p.m.-cut TIM, the actual difference in NSC intake (mean $=0.25 \mathrm{~kg} / \mathrm{d}$ ) was modest. Despite this relatively small difference, it appears that cows preferred the p.m.-cut TIM, resulting in significant, but moderate increases in DMI, yields of milk fat and protein, 4\% FCM, and ECM.

\section{ACKNOWLEDGMENTS}

The authors gratefully thank Sylvie Provencher, Pamela Warburton, and Jocelyne Renaud for sample collection and laboratory analyses at the Dairy and Swine Research and Development Centre (Sherbrooke, QC, Canada). The assistance of Mario Laterrière and Josée Bourassa from the Soils and Crops Research and Development Centre (Quebec City, QC, Canada) for preparation and chemical analyses of forage used in this study is also acknowledged. The statistical advice of Steve Méthot (Dairy and Swine Research and Development Centre; Sherbrooke, QC, Canada) is gratefully acknowledged. The authors also thank Keith Carter and the barn crew for animal care and sampling at the Dairy and Swine Research and Development Centre Farm and the Normandin Research Farm crew for cropping services. Appreciation is extended to Agriculture and Agri-Food Canada for the financial support.

\section{REFERENCES}

Antaya, N. T., R. Berthiaume, G. F. Tremblay, and A. F. Brito. 2015. Short communication: Feeding red clover cut in the afternoon or morning to late-lactation dairy cows. J. Dairy Sci. 98:7335-7339.

AOAC International. 2000. Official Methods of Analysis, 17th ed. AOAC, Arlington, VA.

AOAC International. 2006. Official Methods of Analysis, 18th ed. AOAC, Gaithersburg, MD.
Berg, C. C., A. R. McElroy, and H. T. Kunelius. 1996. Timothy. Pages 643-664 in Cool-Season Forage Grasses. L. E. Moser. D. R. Buxton, and M. D. Casler, ed. American Society of Agronomy, Crop Science Society of America, Soil Science Society of America, Madison, WI.

Bertrand, A., D. Prévost, F. J. Bigras, and Y. Castonguay. 2007. Elevated atmospheric $\mathrm{CO}_{2}$ and strain of rhizobium alter freezing tolerance and cold-induced molecular changes in alfalfa (Medicago sativa L.). Ann. Bot. 99:275-284.

Bertrand, A., G. F. Tremblay, S. Pelletier, Y. Castonguay, and G. Bélanger. 2008. Yield and nutritive value of timothy as affected by temperature, photoperiod and time of harvest. Grass Forage Sci. 63:421-432.

Blakeney, A. B., and L. L. Mutton. 1980. A simple colorimetric method for the determination of sugar in fruit and vegetables. J. Sci. Food Agric. 31:889-897.

Blouin, J. P., J. F. Bernier, C. K. Reynolds, G. E. Lobley, P. Dubreuil, and H. Lapierre. 2002. Effect of supply of metabolizable protein on splanchnic fluxes of nutrients and hormones in lactating dairy cows. J. Dairy Sci. 85:2618-2630.

Borucki Castro, S. I., L. E. Phillip, H. Lapierre, P. W. Jardon, and R. Berthiaume. 2007. Ruminal degradability and intestinal digestibility of protein and amino acids in treated soybean meal products. J. Dairy Sci. 90:810-822.

Bowden, D. D., K. Taylor, and W. E. P. Davis. 1968. Water soluble carbohydrates in orchardgrass and mixed forages. Can. J. Plant Sci. 48:9-15.

Brito, A. F., G. F. Tremblay, A. Bertrand, Y. Castonguay, G. Bélanger, R. Michaud, C. Lafrenière, R. Martineau, and R. Berthiaume. 2014. Alfalfa baleage with increased concentration of nonstructural carbohydrates supplemented with a corn-based concentrate did not improve production and nitrogen utilization in early lactation dairy cows. J. Dairy Sci. 97:6970-6990.

Brito, A. F., G. F. Tremblay, D. R. Ouellet, A. Bertrand, Y. Castonguay, G. Bélanger, R. Michaud, H. Lapierre, and R. Berthiaume. 2008. Alfalfa cut at sundown and harvested as baleage improves milk yield of late-lactation dairy cows. J. Dairy Sci. 91:3968-3982.

Burner, D. M., and D. P. Belesky. 2004. Diurnal effects on nutritive value of alley-cropped orchardgrass herbage. Crop Sci. 44:17761780.

Calder, A. G., K. E. Garden, S. E. Anderson, and G. E. Lobley. 1999 Quantification of blood and plasma amino acids using isotope dilution electron impact gas chromatography/mass spectrometry with $\mathrm{U}-{ }^{13} \mathrm{C}$ amino acids as internal standards. Rapid Commun. Mass Spectrom. 13:2080-2083.

Canadian Council on Animal Care. 1993. Guide to the Care and Use of Experimental Animals. Vol. 1. E. D. Offert, B. M. Cross, and A. A. McWilliam, ed. CCAC, Ottawa, Ontario, Canada.

Delbecchi, L., C. E. Ahnadi, J. J. Kennelly, and P. Lacasse. 2001. Milk fatty acid composition and mammary lipid metabolism in Holstein cows fed protected or unprotected canola seeds. J. Dairy Sci. 84:1375-1381.

Dubois, M., K. A. Gilles, J. K. Hamilton, P. A. Rebers, and F. Smith. 1956. Colorimetric method for determination of sugars and related substances. Anal. Chem. 28:350-356.

Ellis, J. L., J. Dijkstra, A. Bannink, A. J. Parsons, S. Rasmussen, G. R. Edwards, E. Kebreab, and J. France. 2011. The effect of highsugar grass on predicted nitrogen excretion and milk yield simulated using a dynamic model. J. Dairy Sci. 94:3105-3118.

Fisher, D. S., H. F. Mayland, and J. C. Burns. 1999. Variation in ruminants' preference for tall fescue hays cut either at sundown or at sunup. J. Anim. Sci. 77:762-768.

Gaines, W. L., and F. A. Davidson. 1923. Relation between percentage fat content and yield of milk. Bull. 245. Illinois Agric. Exp. Sta., University of Illinois, Urbana.

Gordon, A. J. 1996. Diurnal patterns of photosynthate allocation and partitioning among sinks. Pages 499-517 in Phloem Transport. J. Cronshaw, W. J. Lucas, and R. T. Giaquinta, ed. Liss Inc., New York, NY.

Gregorini, P., M. Eirin, R. Refi, M. Ursino, O. E. Ansin, and S. A. Gunter. 2006. Timing of herbage allocation in strip grazing: Ef- 
fects on grazing pattern and performance of beef steers. J. Anim. Sci. 84:1943-1950.

Gregorini, P., S. A. Gunter, and P. A. Beck. 2008. Matching plant and animal processes to alter nutrient supply in strip-grazed pasture: Timing of herbage and fasting allocation. J. Anim. Sci. 86:10061020.

Hall, M. B. 2000. Neutral detergent-soluble carbohydrates: Nutritional relevance and analysis. A laboratory manual. Univ. Florida Ext. Bull. 339. Gainesville.

Hall, M. B., W. H. Hoover, J. P. Jennings, and T. K. M. Webster. 1999. A method for partitioning neutral detergent soluble carbohydrates. J. Sci. Food Agric. 79:2079-2086.

Hetta, M., J. W. Cone, A.-M. Gustavsson, and K. Martinsson. 2003. The effect of additives in silages of pure timothy and timothy mixed with red clover on chemical composition and in vitro rumen fermentation characteristics. Grass Forage Sci. 58:249-257.

Holm, J., I. Bjorck, A. Drews, and N. G. Asp. 1986. A rapid method for the analysis of starch. Starke 38:224-226.

Huhtanen, P. J., H. O. Miettinen, and V. F. J. Toivonen. 1997. Effects of silage fermentation and post-ruminal casein supplementation in lactating dairy cows: 1 - diet digestion and milk production. J. Sci. Food Agric. 74:450-458.

Huntington, G. B., and J. C. Burns. 2007. Afternoon harvest increases readily fermentable carbohydrate concentration and voluntary intake of gamagrass and switchgrass by beef steers. J. Anim. Sci. 85:276-284.

Karkalas, J. J. 1985. An improved enzymatic method for the determination of native and modified starch. J. Sci. Food Agric. 36:10191027.

Lapierre, H., G. E. Lobley, L. Doepel, G. Raggio, H. Rulquin, and S. Lemosquet. 2012. Triennial Lactation Symposium: Mammary metabolism of amino acids in dairy cows. J. Anim. Sci. 90:1708-1721.

Lechtenberg, V. L., D. A. Holt, and H. W. Youngberg. 1971. Diurnal variation in nonstructural carbohydrates in vitro digestibility, and leaf to stem ratio of alfalfa. Agron. J. 63:719-724.

Martineau, R., H. Lapierre, D. R. Ouellet, D. Pellerin, and R. Berthiaume. 2007. Effects of method of conservation of timothy on nitrogen metabolism in lactating dairy cows. J. Dairy Sci. 90:28702882

Martineau, R., J. G. Proulx, C. Côrtes, A. F. Brito, and T. F. Duffield 2015. Two-stage rumen cannulation technique in dairy cows. Vet. Surg. 44:551-556.

Mayland, H. F., G. E. Shewmaker, P. A. Harrison, and N. J. Chatterton. 2000. Nonstructural carbohydrates in tall fescue cultivars: Relationship to animal preference. Agron. J. 92:1203-1206.

McCutcheon, S. N., and D. E. Bauman. 1986. Effect of chronic growth hormone treatment on response to epinephrine and thyrotropinreleasing hormones in lactating cows. J. Dairy Sci. 69:44-51.

Miller, L. A., J. M. Moorby, D. R. Davies, M. O. Humphreys, N. D Scollan, J. C. MacRae, and M. K. Theodorou. 2001. Increased concentration of water-soluble carbohydrate in perennial ryegrass (Lolium perenne L.): Milk production from late-lactation dairy cows. Grass Forage Sci. 56:383-394.

Moorby, J. M., R. T. Evans, N. D. Scollan, J. C. MacRae, and M. K. Theodorou. 2006. Increased concentration of water-soluble carbohydrate in perennial ryegrass (Lolium perenne L.). Evaluation in dairy cows in early lactation. Grass Forage Sci. 61:52-59.

Morin, C., G. Bélanger, G. F. Tremblay, A. Bertrand, Y. Castonguay, R. Drapeau, R. Michaud, R. Berthiaume, and G. Allard. 2011. Diurnal variations of non-structural carbohydrates and nutritive value in alfalfa. Crop Sci. 51:1297-1306.

Morin, C., G. Bélanger, G. F. Tremblay, A. Bertrand, Y. Castonguay, R. Drapeau, R. Michaud, R. Berthiaume, and G. Allard.
2012. Short Communication: Diurnal variations of nonstructural carbohydrates and nutritive value in timothy. Can. J. Plant Sci. 92:883-887.

Narasimhalu, P., L. J. Halliday, J. B. Sanderson, H. T. Kunelius, and K. Winter. 1992. The composition, intake, and digestibility of timothy silage preserved untreated or treated with formic acid or a cellulase-hemicellulase preparation. Can. J. Anim. Sci. 72:431-434.

Novozamsky, I., R. van Eck, J. C. van Schouwenburg, and I. Walinga. 1974. Total nitrogen determination in plant material by means of the indophenol-blue method. Neth. J. Agric. Sci. 22:3-5.

NRC. 2001. Nutrient Requirements of Dairy Cattle. 6th rev. ed. Natl. Acad. Sci., Washington, DC.

Orth, R. 1992. Sample Day and Lactation Report. DHIA 200 FactSheet A-2. Mid-States Dairy Records Processing Center, Ames, IA.

Owens, V. N., K. A. Albrecht, and R. E. Muck. 2002. Protein degradation and fermentation characteristics of unwilted red clover and alfalfa silage harvested at various times during the day. Grass Forage Sci. 57:329-341.

Pagano, R. I. B. Valenti, A. De Angelis, M. Avondo, and P. Pennisi. 2011. Morning versus afternoon cutting time of Berseem clover (Trifolium alexandrinum L.) affects feed intake, milk yield and composition in Girgentana goats. J. Dairy Res. 78:500-504.

Patton, R. A., A. N. Hristov, C. Parys, and H. Lapierre. 2015. Relationships between circulating plasma concentrations and duodenal flows of essential amino acids in lactating dairy cows. J. Dairy Sci 98:4707-4734.

Pelletier, S., G. F. Tremblay, G. Bélanger, A. Bertrand, Y. Castonguay, D. Pageau, and R. Drapeau. 2010. Forage nonstructural carbohydrates and nutritive value as affected by time of cutting and species. Agron. J. 102:1388-1398.

Pelletier, S., G. F. Tremblay, C. Lafrenière, A. Bertrand, G. Bélanger, Y. Castonguay, and J. Rowsell. 2009. Nonstructural carbohydrate concentrations in timothy as affected by $\mathrm{N}$ fertilization, stage of development, and time of cutting. Agron. J. 101:1372-1380.

Simon, U., and B. H. Park. 1983. A descriptive scheme for stages of development in perennial forage grasses. Pages 416-418 in Proc. XIV Int. Grassland Congress, Lexington, KY. J. A. Smith and V. W. Hays, ed. Westview Press, Boulder, CO.

Smit, H. J., S. Tamminga, and A. Elgersma. 2006. Dairy cattle grazing preference among six cultivars of perennial ryegrass. Agron. J. 98:1213-1220.

Suzuki, M. 1993. Fructans in crop production and preservation. Pages 227-255 in Science and Technology of Fructans. CRC Press, Boca Raton, FL.

Tremblay, G. F., C. Morin, G. Bélanger, A. Bertrand, Y. Castonguay, R. Berthiaume, and G. Allard. 2014. Silage fermentation of PMand AM-cut alfalfa wilted in wide and narrow swaths. Crop Sci. $54: 439-452$

Van Soest, P. J., J. B. Robertson, and B. A. Lewis. 1991. Methods for dietary fiber, neutral detergent fiber, and nonstarch polysaccharides in relation to animal nutrition. J. Dairy Sci. 74:3583-3597.

Yari, M., R. Valizadeh, A. A. Naserian, A. Jonker, A. Azarfard, and P. Yu. 2014. Effects of including alfalfa hay cut in the afternoon or morning at three stages of maturity in high concentrate rations on dairy cows performance, diet digestibility and feeding behavior. Anim. Feed Sci. Technol. 192:62-72.

Yari, M., R. Valizadeh, A. A. Naserian, A. Jonker, and P. Yu. 2012. Modeling nutrient availability of alfalfa hay harvested at three stages of maturity and in the afternoon and morning in dairy cows. Anim. Feed Sci. Technol. 178:12-19. 